\title{
Onlap, offlap, and the origin of unconformity-bounded depositional sequences
}

\author{
Nicholas Christie-Blick \\ Department of Geological Sciences and Lamont-Doherty Geological Observatory of Columbia University, Palisades, NY \\ 10964, USA
}

(Received June 18 1990; revision accepted September 20 1990)

\begin{abstract}
Christie-Blick, N., 1991. Onlap, offlap, and the origin of unconformity-bounded depositional sequences. Mar. Geol., 97: 35-56.

Unconformity-bounded depositional sequences represent the fundamental building blocks of sedimentary successions. They are typically characterized by onlap at the base and by offlap at the top, and they tend to be markedly asymmetrical, with onlap accounting for a larger part of any cycle of sedimentation than offlap. Offlap cannot be attributed solely to erosional truncation, but instead implies that sequence boundaries develop over a finite interval of time. Depositional sequences are commonly associated with a cyclic arrangement of facies, but transgressive-regressive cycles are out of phase with respect to sequence boundaries, which in down-dip locations are both overlain and underlain by progradational deposits, and hence form during times of regression of the shoreline.

These observations are used to develop some ideas about the origin of unconformity-bounded sequences, with reference to the inter-related roles of changes in depositional base level and sediment supply. In particular, it is shown than onlap and offlap are due to lateral migration of a "line of critical bypassing", defined so as to incorporate the effects of sediment loading and compaction as well as the rate of change of elevation with respect to sea level. Downward shifts in onlap may be achieved by either an increase in the rate of eustatic fall or a decrease in the rate of tectonic subsidence, and it is premature to assume that eustatic and tectonic controls on sea level may be distinguished solely on the basis of the frequency of depositional cyclicity. Small shifts in the position of onlap can also be produced by changes in sediment supply, and more attention needs to be paid to the influence of sediment supply in the development of minor boundaries. Unconformities related to eustatic fluctuations are thought to correspond approximately to times of relatively rapid sea-level fall (inflection points), but questions remain about the existence of possible leads and lags of up to $\frac{1}{4}$ cycle, and hence about the degree to which sequence boundaries of eustatic origin may vary in age both within a given basin and from one basin to another.
\end{abstract}

\section{Introduction}

The sedimentary record is fundamentally discontinuous at a variety of scales as a result of secular changes in patterns of erosion, transport, in situ production and accumulation of sediment (Barrell, 1917; Wheeler, 1958; Sloss, 1963, 1988; Frazier, 1974; Vail et al., 1977, 1984; Ager, 1981; Dott, 1983;

This article was originally submitted for publication in a special issue of Marine Geology on "The Record of Sea-Level Fluctuation". When the special issue was transferred to Sedimentary Geology, the author requested that the full version of the paper be published in a regular issue of Marine Geology, and that an extended abstract be included in the special issue (Sedimentary Geology, Vol. 70).
James, 1984; Schlee, 1984; Berg and Woolverton, 1985; International Subcommission on Stratigraphic Classification, 1987; Vail, 1987; Van Wagoner et al., 1987, 1988, 1990; James and Leckie, 1988; Galloway, 1989). Stratigraphic discontinuities (unconformities) are expressed by breaks in facies or biotic successions and by geometric patterns of stratal onlap and offlap that are in places directly observable in outcrop (e.g., Bosellini, 1984, 1988; Mutti, 1985; Sarg, 1988, 1989; GarcíaMondéjar and Fernández-Mendiola, 1989, 1991) and well-log cross sections (e.g., Van Wagoner et al., 1990; Mitchum and Van Wagoner, 1991), and imaged in seismic reflection profiles (e.g., Vail et al., 1977, 1984; Berg and Woolverton, 1985; 
Bally, 1987, 1988, 1989; Eberli and Ginsburg, 1989). Relatively conformable successions of genetically related strata bounded by unconformities and their correlative conformities are termed depositional sequences (Mitchum, 1977; Vail, 1987; Van Wagoner et al., 1987, 1988, 1990), and the recognition of such sequences forms the basis of the rapidly developing fields of seismic and sequence stratigraphy (for alternative usage of the term sequence, see International Subcommission on Stratigraphic Classification, 1987; Galloway, 1989).

There is general agreement that patterns of sediment accumulation and preservation are controlled largely by the interaction of subsidence, eustasy and sediment supply, and less directly or to a lesser extent by such factors as topography, climate, river discharge and ambient oceanographic conditions (Pitman, 1978, 1990; Pitman and Golovchenko, 1983; Watts and Thorne, 1984; Burton et al., 1987; Helland-Hansen et al., 1988; Jervey, 1988; Kendall and Lerche, 1988; Posamentier et al., 1988; Sarg, 1988; Angevine, 1989; Butcher, 1989; Galloway, 1989; Christie-Blick et al., 1990; Jordan and Flemings, 1990; Lawrence et al., 1990; Reynolds et al., 1990; Thorne and Swift, 1990). A key notion, and one that is perhaps selfevident, is that sediments accumulate at a given site only to the extent that space (or accommodation) is available for them. However, serious questions remain about precisely how patterns of sedimentation respond to changes in accommodation or sediment supply, and especially about how variations in these controls may influence the timing of unconformity development (Posamentier et al., 1988; Christie-Blick et al., 1990; Jordan and Flemings, 1990; Reynolds et al., 1990). For example, given the fact that sediments accumulate both above and below sea level, what actually limits the accommodation at a particular locality at a particular time? To what extent do sequence boundaries have time-stratigraphic significance within a given sedimentary basin, and to what extent are they either diachronous (Johnson, 1987; Christie-Blick et al., 1990) or composed in different places of several closely spaced but stratigraphically distinct surfaces? With what resolution are sequence boundaries of eustatic origin in different basins both correlative (that is, related to the same eu- static events) and of the same age (Christie-Blick, 1990; Christie-Blick et al., 1990; Jordan and Flemings, 1990; Reynolds et al., 1990)?

The purpose of this article is to develop some simple ideas about the origin of unconformitybounded depositional sequences, focussing especially on the surfaces themselves, and to draw attention to some implications for the problem of gauging eustatic change from the stratigraphic record. The main contribution is to extend concepts of backstripping (Steckler and Watts, 1978) and geohistory analysis (Van Hinte, 1978) to show how conditions for the development of an unconformity can be quantified in terms of rates of tectonic subsidence, sediment accumulation, eustatic change and change in elevation with respect to the sea surface. This last term is analogous to the water depth term of the conventional backstripping equation, but it takes into account the different isostatic response for sediments deposited above sea level.

\section{Basic observations}

Observations distilled from numerous examples of unconformity-bounded depositional sequences in both the subsurface and outcrop indicate that facies are arranged in a systematic way with respect to stratal geometry (Fig.1) (Haq et al., 1987, 1988; Vail, 1987; Van Wagoner et al., 1987, 1988, 1990; Sarg, 1988). Details vary of course, according to tectonic and paleogeographic setting, sediment type and eustatic history, and as a function of scale, but certain attributes appear to be generally present, independent of age and setting. Even at different scales, depositional sequences are very similar (Fulthorpe and Carter, 1989; García-Mondéjar and Fernández-Mendiola, 1989, 1991; Van Wagoner et al., 1990; Mitchum and Van Wagoner, 1991; N. Christie-Blick, unpublished data), and the distinction of orders of sequences is for the most part arbitrary and site-dependent. Here, to provide a common basis for discussion, I briefly review the most important attributes of depositional sequences, with particular reference to two well known seismic examples. Information is drawn both from existing literature and from my 


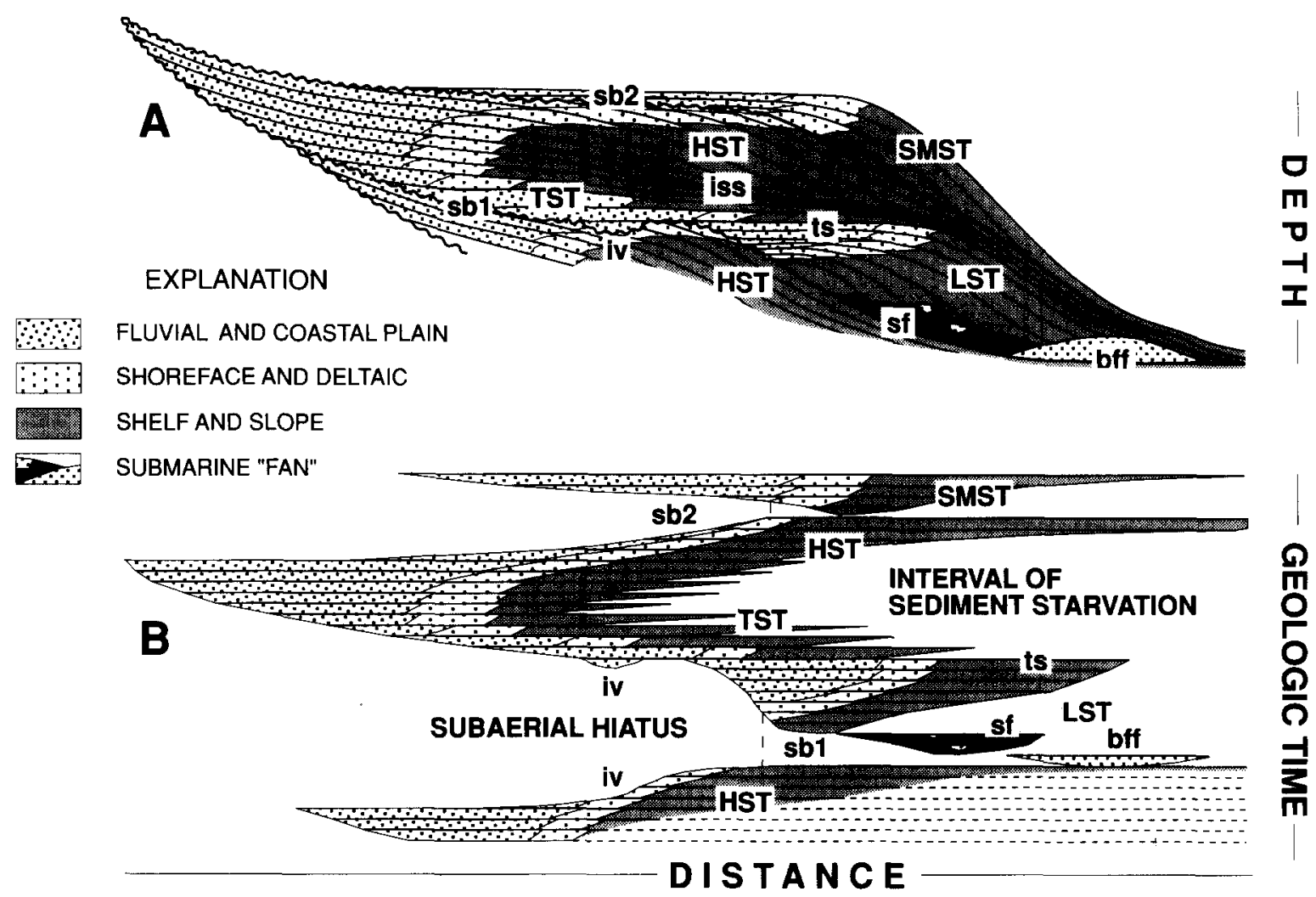

Fig. 1. Conceptual cross sections in relation to depth (A) and geological time (B) showing stratal geometry, systems tracts and the distribution of siliciclastic facies within unconformity-bounded depositional sequences deposited in a basin with a shelf break (modified from Vail, 1987, specifically to include offlap). Systems tracts: $S M S T=$ shelf margin; $H S T=$ highstand; $T S T=$ transgressive; $L S T=$ lowstand. Sequence boundaries: $s b 2=$ type $2 ; s b I=$ type 1 . Other abbreviations: $i s s=$ interval of sediment starvation; $t s=$ transgressive surface (corresponding to the time of maximum regression); $i v=$ incised valley; $s f=s l o p e$ fan; $b f f=b a s i n$ floor fan. Note that in the seismic stratigraphic literature the term submarine "fan" includes a variety of turbidite systems and sediment gravity flow deposits that are not necessarily fan-shaped.

own experience in sequence stratigraphic studies during the past decade.

\section{Stratal geometry}

Unconformity-bounded depositional sequences are typically characterized by stratal onlap at the base (in marine, coastal and non-marine settings) and by offlap at the top (Fig.2). By onlap and offlap we mean the progressive up-dip termination of strata against an underlying and overlying surface, respectively (Swain, 1949; Mitchum, 1977). Offlap includes both toplap, in which stratal termination is inferred to be due largely to progradation and sedimentary bypassing, and erosional truncation, in which stratal relations are due at least in part to the removal of previously deposited sediment. Strata that terminate in one direction by onlap or offlap may terminate in another by downlap, and downlap surfaces are therefore present both within and at the base of depositional sequences ( $d l s$ in Fig.2) (Vail et al., 1984; Vail, 1987; cf. Hubbard, 1988). In three dimensions, an individual stratum may also terminate by both onlap and offlap, as well as by downlap. This is especially the case if the underlying unconformity is characterized by significant topographic relief, as in some fault-controlled basins such as grabens for example. Apparent geometry necessarily varies from one seismic reflection profile or cross section to another, and in some cases the discordance between a sequence boundary and overlying and 


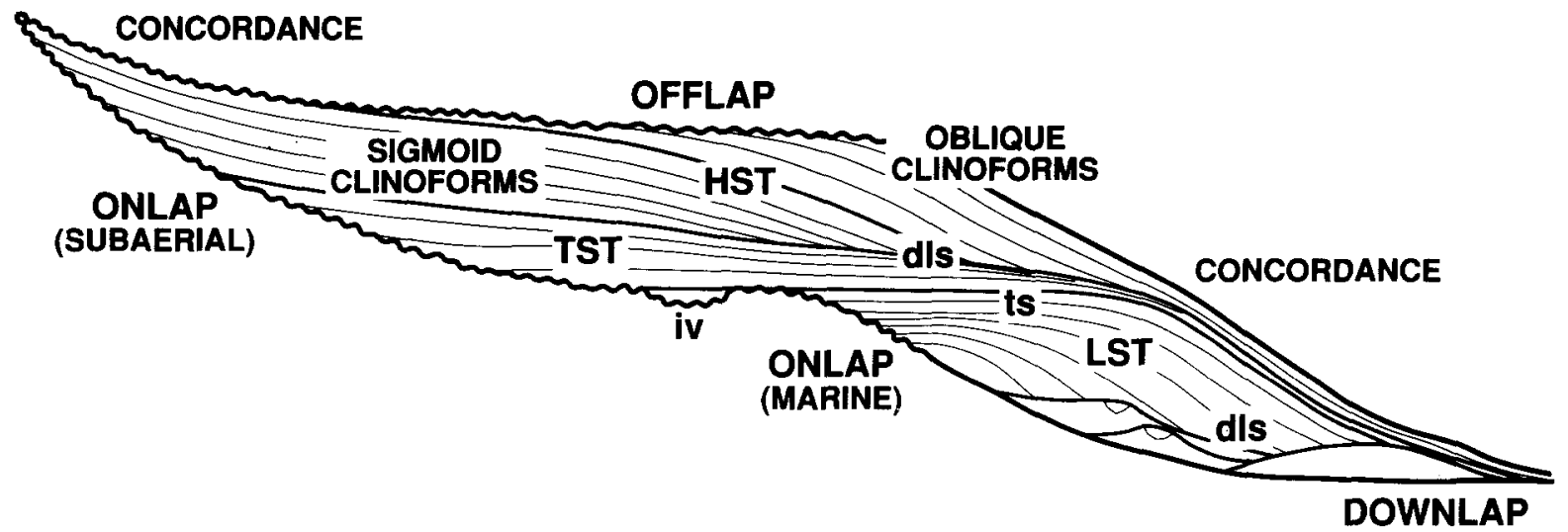

Fig.2. Conceptual cross section illustrating stratal geometry within an unconformity-bounded depositional sequence (simplified from Fig.1). The transition from stratal onlap to offlap, and the corresponding transition from sigmoid to oblique clinoforms, is located within the highstand systems tract $(H S T)$. Other systems tracts: $T S T=$ transgressive; $L S T=$ lowstand. Other abbreviations: $d l s=$ downlap surface within the sequence; $t s=$ transgressive surface; $i v=$ incised valley.

underlying strata may be too subtle to be resolved at the scale of observation.

Sequences tend to be markedly asymmetrical, with stratal onlap commonly accounting for a larger part of any cycle of deposition than stratal offlap, and clinoforms associated with progradation in the upper part of a given sequence typically evolve from a sigmoid to an oblique configuration (Fig.2) (Vail, 1987; Sarg, 1988) ${ }^{1}$. This geometric asymmetry of depositional sequences is also responsible for the familiar sawtooth shape of the coastal onlap curve (Fig.3A). However, the existence of offlap demonstrates that in general sequence boundaries develop over a finite interval of time, and not instantaneously. Offlap cannot be attributed solely to erosional truncation of originally sigmoid clinoforms. In many cases this would require an unreasonable amount of erosion, as well as a marked increase in the sediment supply in order to account for observed progradation. The horizontal segments of the coastal onlap curve are therefore artifacts, representing no more than the conventional ages of unconformities, and they

\footnotetext{
${ }^{1}$ By sigmoid clinoforms we mean those that flatten out up dip and onlap against an underlying sequence boundary. Oblique clinoforms are associated with offlap (Mitchum et al., 1977, fig.6). Note that this terminology differs from that of Vail (1987, fig.6), who refers to prograding clinoforms as offlapping for both sigmoid and oblique configurations; and also from that of Bosellini (1984, fig.7), who restricts the term offlap specifically to sigmoid stratal geometry, that is, prograding depositional units with concordant upper boundaries.
}

do not indicate the manner in which sequence boundaries actually form (cf. Posamentier et al., 1988). I have argued elsewhere that coastal onlap curves are of limited utility because they cannot be constructed or compared objectively (ChristieBlick et al., 1988, 1990). If the purpose of such a curve is to display variations in the up-dip extent of strata within depositional sequences, then it ought to consist of two oblique segments, a lower one representing onlap and an upper one representing the offlap phase (Fig.3B).

The gross geometrical features of depositional sequences are common to both terrigenous and carbonate-dominated successions, and are illustrated in Figs. 4 and 5 by means of seismic reflection profiles reproduced from A.W. Bally's "Atlas of Seismic Stratigraphy" (Bally, 1987, 1988, 1989). Miocene strata of the Baltimore Canyon trough, offshore New Jersey, provide an example of sequence development in a terrigenous ramp setting on a thermally old passive continental margin (Fig.4) (Greenlee, 1988; Greenlee, and Moore, 1988). Strata of mid-Permian age in the Midland basin of west Texas illustrate mixed carbonate and siliciclastic sequences along the northern outer margin of a foreland basin peripheral to the Marathon thrust and fold belt (Fig.5) (Sarg, 1988, 1989). In each case, sequence boundaries are indicated by bold lines, and reflection terminations by arrows. Onlap and downlap are observed at the base of many depositional sequences. Offlap is 

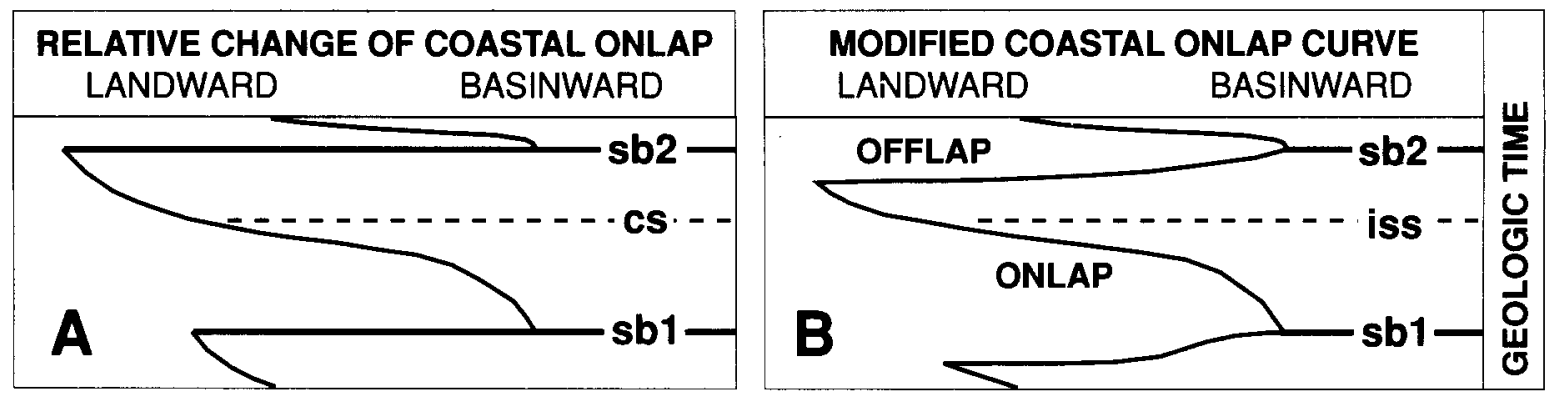

Fig.3. (A) A diagrammatic coastal onlap curve of the sort that would conventionally be distilled from cross sections like the one shown in Fig.1 (e.g., Haq et al., 1987, 1988). (B) A modified coastal onlap curve that incorporates the existence of offlap beneath each of the sequence boundaries shown. Note that the time of maximum onlap in a given sequence systematically predates the upper boundary of the sequence, as it is dated at a correlative conformity. Abbreviations: $s b l$ and $s b 2=$ type 1 and type 2 sequence boundaries; $c s=$ condensed section; iss =interval of sediment starvation of this paper (a term that specifies the process of condensation; Christie-Blick, 1990).

well developed at several horizons, especially at sequence boundaries 13.8 and 12.5 in Fig.4, and at the tops of sequences 1, 2 and 3 in Fig.5.

Although sediments commonly prograde from areas of low subsidence rate to areas of higher subsidence rate, as in the above examples, this is not necessarily the case. For example, some carbonate platforms with well developed rims prograde continentward, towards their lagoons (Aitken, 1978; Grotzinger, 1986), and siliciclastic sedimentary systems on the inner margins of foreland basins also tend to prograde towards areas of less rapid subsidence (Allen and Homewood, 1986). The result of this different arrangement of depocentres with respect to the sediment transport direction is to accentuate offlap where the subsidence rate is relatively low, and stratal concordance where the subsidence rate is high (e.g., Swift et al., 1987).

\section{Time-stratigraphic significance of sequence boundaries}

The geometrical characteristics of depositional sequences are consistent with the observation that the hiatus represented by a subaerial unconformity (sequence boundary) tends to be greatest in areas for which the rate of subsidence is low, generally at basin margins, and least where unconformities pass laterally into correlative conformities (Fig.1B). Conformities are commonly located within marine deposits and where rates of subsi- dence and sediment accumulation are high. Despite the obvious diachroneity of strata immediately above or below a sequence boundary at basin margins (e.g., Johnson, 1987), most such boundaries have time-stratigraphic significance at the resolution of available dating methods. That is, strata overlying an unconformity tend to be everywhere younger than strata underlying it. Few unconformities are themselves demonstrably diachronous $^{2}$ (Christie-Blick et al., 1990), and it is this property that allows the assignment of a specific age at a correlative conformity.

\section{Facies arrangements with respect to sequence boundaries}

Patterns of stratal onlap and offlap are associated with cyclical changes in palaeobathymetry and shoreline position, and hence with the development within each sequence of a cyclical arrangement of depositional facies. Transgressiveregressive cycles are, however, out of phase with respect to sequence boundaries, which in downdip locations are both overlain and underlain by progradational deposits, and hence form during times of overall regression of the shoreline (Fig.1).

In detail, sequence boundaries exhibit a range of characteristics, but two main types exist (Haq

\footnotetext{
${ }^{2} \mathrm{~A}$ diachronous unconformity is one that at a given locality is overlain by strata that are older than strata below the unconformity at a different locality (Christie-Blick et al., 1990).
} 
et al., 1987, 1988; Vail, 1987; Van Wagoner et al., 1987, 1988, 1990; Posamentier et al., 1988; Sarg, 1988). Type 1 boundaries are characterized by subaerial exposure, valley incision and locally marked erosion of both marine and non-marine sediments, by deposition preferentially in deeper water (e.g., turbidite systems and platform-derived allodapic carbonate breccias), and at least in places by a facies discontinuity involving abrupt upward shoaling. For example, shallow-marine terrigenous mudstone might be overlain directly by fluvial sandstone, or subtidal carbonate mudstone might be overlain by supratidal microbial laminites, in each case without evidence for the preservation of intermediate facies. Outcrop examples of such relations have been documented by Christie-Blick and Levy (1989) and by Grotzinger (1986) in rocks of Proterozoic age in the western United States and Canada, indicating that the fundamental controls on sedimentation have been the same throughout geological time! Type 2 sequence boundaries lack prominent facies discontinuities, and downward shifts in onlap are restricted to areas landward of the shoreline. Such subtle stratigraphic discontinuities are identified with comparative difficulty, especially in outcrop and in borehole logs. However, both types of boundary tend to be associated with a transition in the stacking pattern of higher-order sequences or parasequences, from increasingly progradational (a forestepping pattern; Christie-Blick, 1990) to increasingly aggradational (Van Wagoner et al., 1987, 1988, 1990; Posamentier and Vail, 1988). An outcrop example, associated with a type 1 boundary, is present in the Gallup Sandstone (Cretaceous) of New Mexico (Nummedal et al., 1989; Nummedal, 1990). To the extent that such stacking patterns can be observed, even subtle type 2 sequence boundaries may be recognizable. The main difficulty is that the manner in which parasequences are stacked may not be obvious, and especially in the case of type 2 boundaries, the change in stacking may not correspond exactly with the location of the sequence boundary.

As a result of the phase lag between transgressive-regressive cycles and corresponding sequence boundaries, unconformity-bounded depositional sequences are divisible into three systems tracts (lithofacies assemblages) (Brown and Fisher, 1977; Van Wagoner et al., 1987, 1988). These are the lowstand and shelf-margin systems tracts, overlying type 1 and type 2 sequence boundaries, respectively, and characterized by forestepping to aggradational stacking of parasequences (stippled pattern in Fig.5); the transgressive systems tract, characterized by a backstepping arrangement of parasequences; and the highstand systems tract, characterized by an aggradational to forestepping stacking pattern (Van Wagoner et al., 1987, 1988, 1990; Posamentier and Vail, 1988; Posamentier et al., 1988; Sarg, 1988; Christie-Blick, 1990). Although these systems tracts are commonly interpreted in terms of eustatic fluctuation, as suggested by the names selected, they are actually descriptive entities and do not require any preconceived notions about the role of eustasy in the origin of sedimentary cyclicity. Moreover, the term transgressive systems tract does not imply that all of the sediments contained within it are either marine or necessarily deposited during transgression. Individual parasequences tend to shoal upwards, and where abundant sediment is available, in both siliciclastic- and carbonate-dominated settings it is not necessary for either the shoreline position or the water depth to change much prior to deposition of the next highstand (a "keep-up" situation in the parlance of Kendall and Schlager, 1981; and Sarg, 1988). By definition, the top of the lowstand and shelf-margin systems tracts corresponds to the time of maximum regression of the shoreline, and is commonly marked by a prominent marine flooding surface (transgressive surface of Van Wagoner et al., 1987, 1988). The boundary between the transgressive and highstand systems tracts corresponds to an interval of sediment starvation (condensed section of Van Wagoner et al., 1987, 1988; Loutit et al., 1988), to the time of maximum transgression, and in many cases to a regional downlap surface ( $d l s$ in Fig.2, and dashed lines in Figs.4 and 5).

\section{Drowning unconformities}

A "drowning unconformity" is a discontinuity created by the drowning of a carbonate platform either as a result of submergence beneath the 


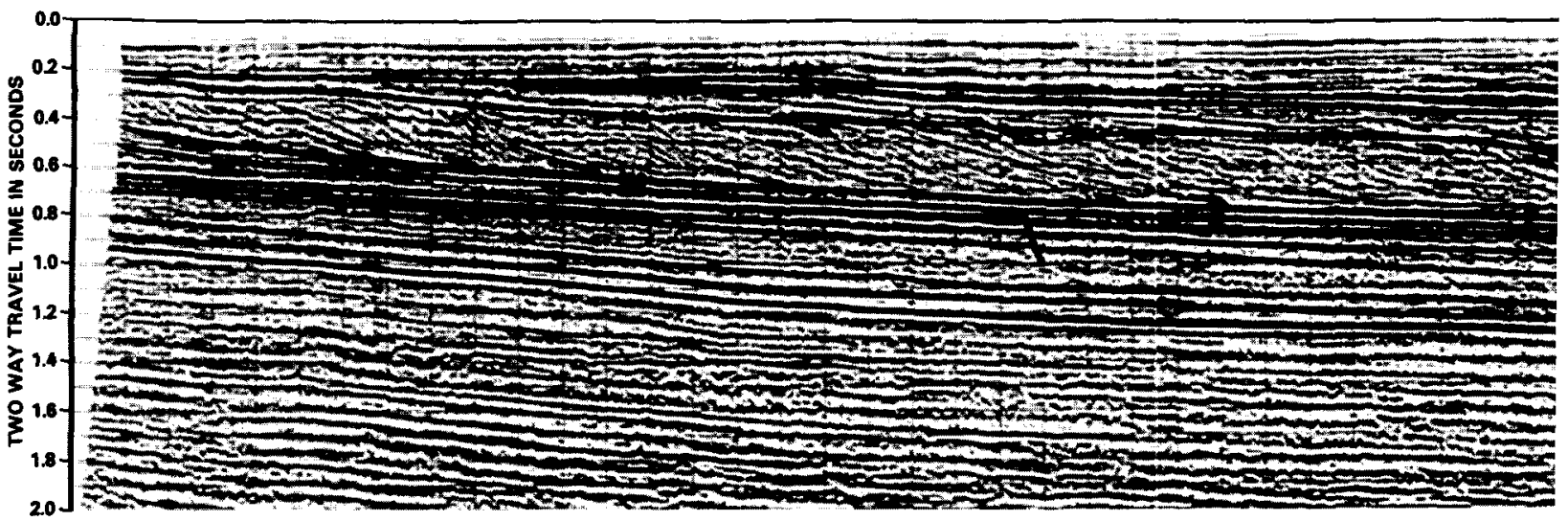

Fig.4. Interpreted seismic section from the Baltimore Canyon trough, offshore New Jersey (reproduced with permission, from Gre interpreted ages in millions of years. are indicated by bold lines and refiection terminations, by arrows. Downlap surfaces $(D L S)$ are

$\mathbf{s}$

\section{HAMON SWMison}<smiles></smiles>

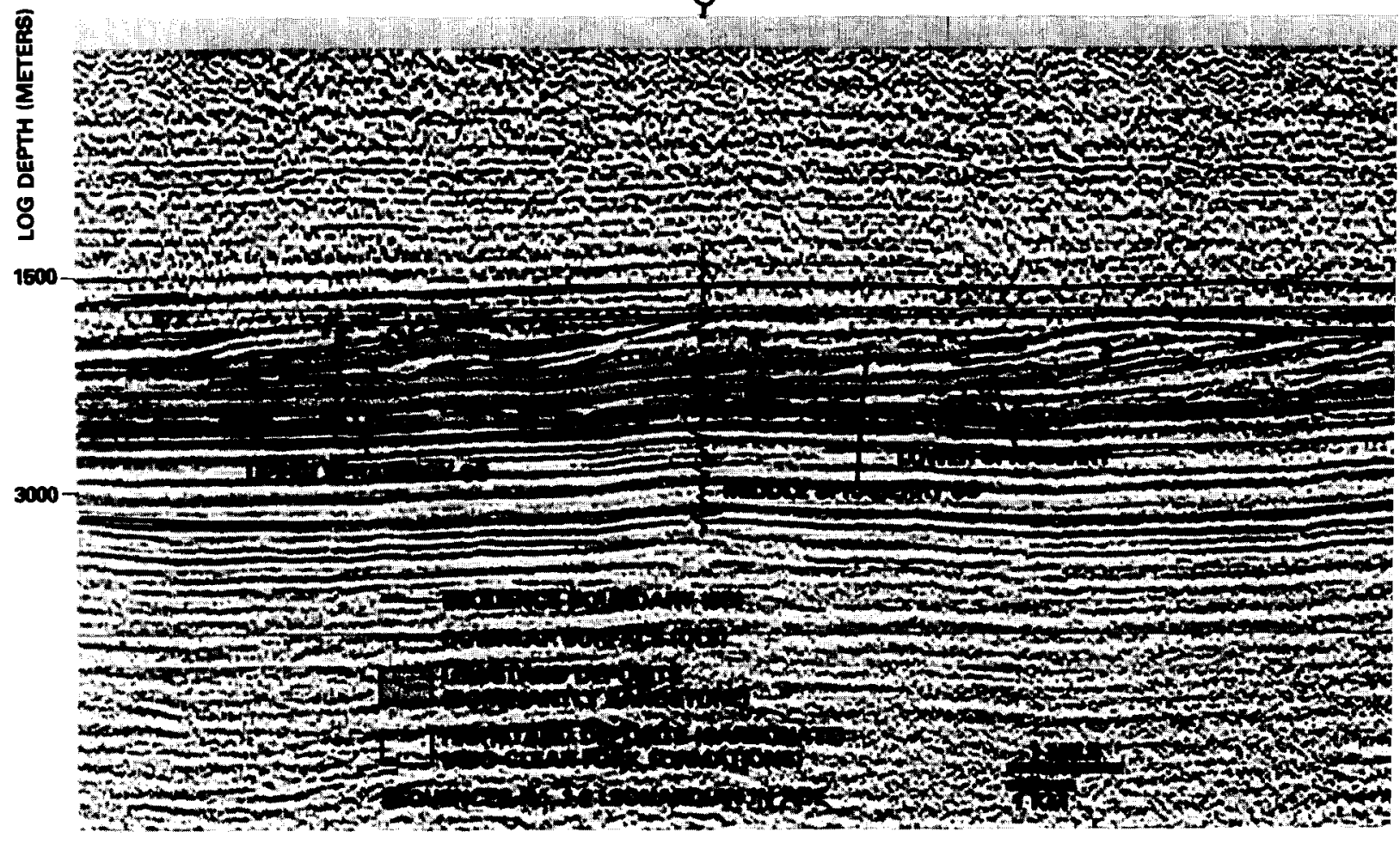

Fig.5. Interpreted seismic section from the Midland basin, west Texas (reproduced with permission, from Sarg, 1989). Deposi lithostratigraphic units. 


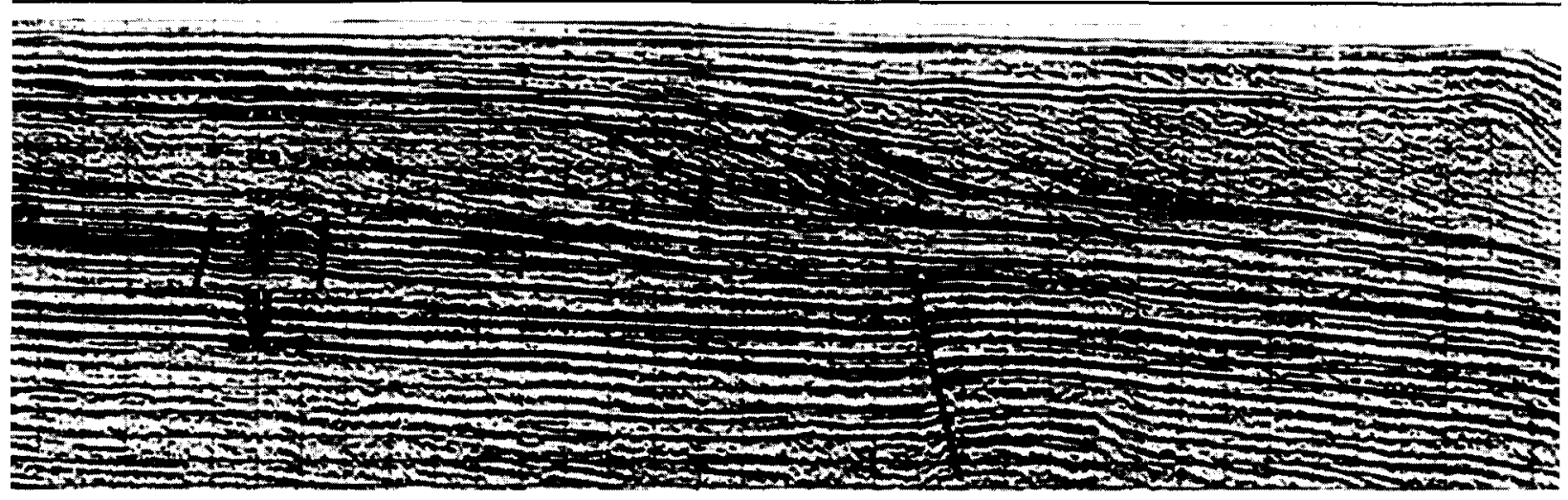

ith

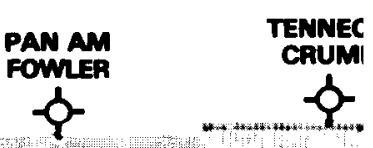

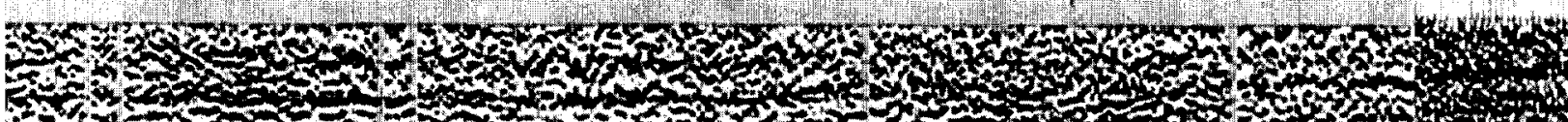

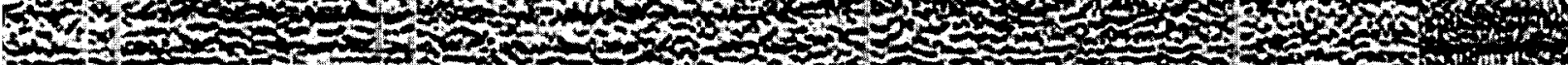

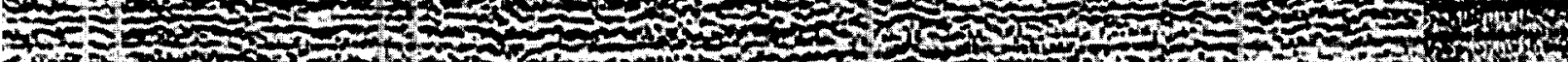
IF,

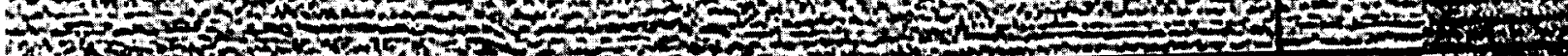

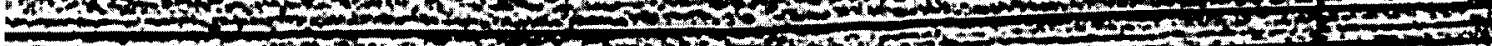

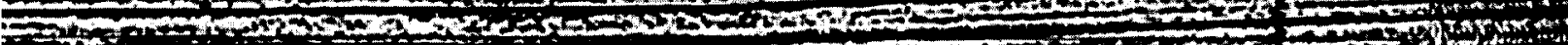

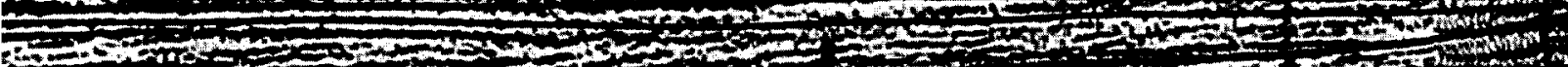
-

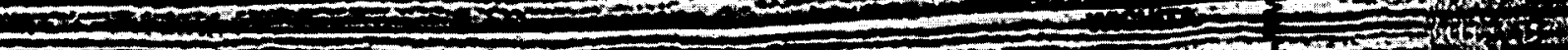

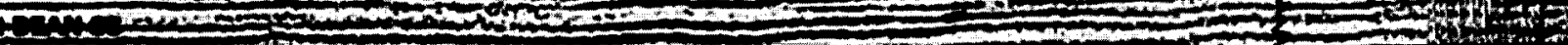

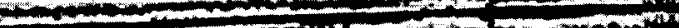

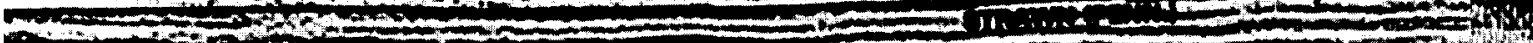

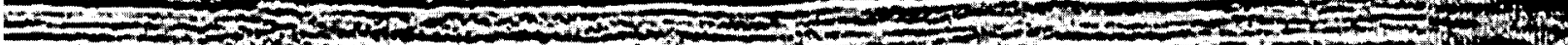

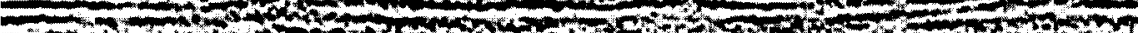

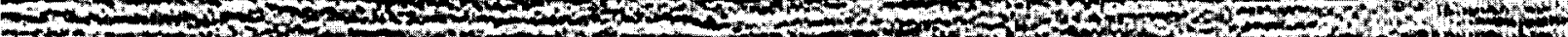

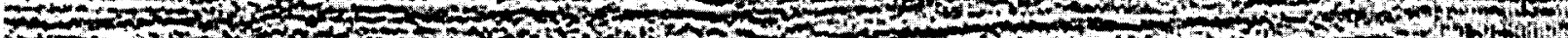

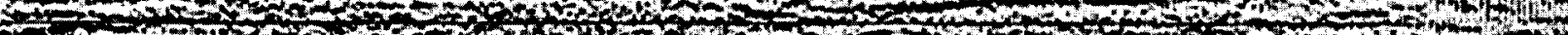

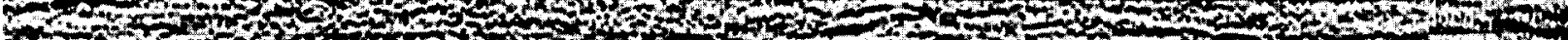

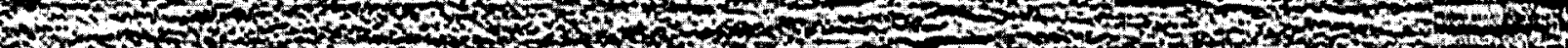

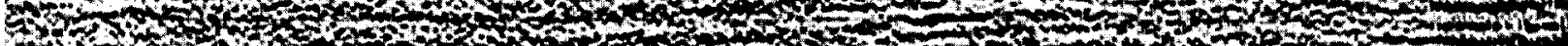

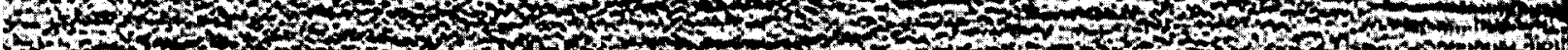

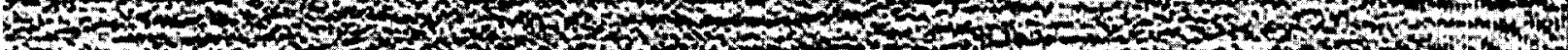

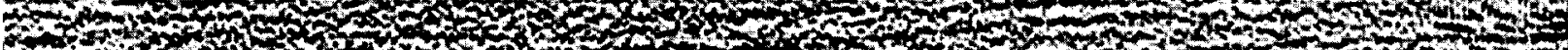
P. 
photic zone or through burial by prograding marine siliciclastic sediments or volcanic rocks at a relatively high stand of sea level (Schlager and Camber, 1986; Schlager, 1989). These authors recognized that siliciclastic sediments commonly accumulate on gentler slopes than carbonate sediments, and they proposed the concept of a drowning unconformity as an alternative explanation for the stratal onlap associated with sequence boundaries. This interpretation is plausible from a geometrical point of view, but it is not consistent with the distribution of sedimentary facies. Drowned platforms are typically overlain by deeper-water siliciclastic or pelagic sediments, in many cases with an intervening starvation interval or marine hardground (Schlager, 1981), and in the parlance of this paper and most of the sequence stratigraphic literature drowning unconformities are flooding and/or downlap surfaces within unconformitybounded depositional sequences (Fig.1).

Sequence boundaries in carbonate rocks are associated with (1) geographically restricted lowstand deposits consisting of allochthonous slope and platformal debris, and siliciclastic sediment preferentially transported into the deeper basin while the platform was exposed or partially exposed, (2) evidence for erosion in both slope and platform settings, in some cases with incised valleys filled by fluvial sediment, and (3) evidence for meteoric diagenesis, including the development of karst (Sarg, 1988, 1989; García-Mondéjar and Fernández-Mendiola, 1989, 1991). Problems in interpretation arise when sequence boundaries become amalgamated with flooding surfaces or are simply less obvious than such surfaces, and evidence for platform exposure is not well developed. This appears to be the case, for example, with the interpretation of the well-known belt of reefal platforms of Middle to Late Devonian age that crop out along the northern margin of the Canning basin in Western Australia (Playford, 1980; Playford et al., 1989). Backstepping of the platforms in Frasnian time and the termination of reef growth in the Famennian are ascribed quite reasonably by Playford to abrupt rises in relative sea level and drowning, but recent work in co-operation with Playford and the Australian Bureau of Mineral Resources suggests the existence of several unconformity-bounded depositional sequences within the same strata. The preservation of evidence for exposure depends on the degree and duration of exposure, on the climate (including rainfall), and on whether appreciable erosion took place during subsequent transgression.

Related to the concept of a drowning unconformity is an idea recently advanced by Pitman (1990) that in terrigenous settings also even type 1 sequence boundaries may be due to marine erosion during intervals of regional transgression. Erosion is known to take place in both the offshore marine environment and the shoreface (e.g., the ravinement process of Swift, 1968; Demarest and Kraft, 1987; Nummedal and Swift, 1987; Penland et al., 1988; Swift and Thorne, 1990). However, as in carbonate rocks, sequence boundaries and flooding surfaces are stratigraphically distinct and can usually be differentiated (e.g., Nummedal and Swift, 1987; Baum and Vail, 1988; Christie-Blick and Levy, 1989; Van Wagoner et al., 1990; Weimer, 1990). Pitman's interpretation of sequence boundaries is incompatible with available geological observations.

\section{Origin of unconformities}

A qualitative conclusion to be drawn from these basic observations is that the origin of unconformities and the development of offlap-onlap geometry can be considered in terms of the expansion and subsequent burial of zones of non-deposition or erosion. In non-marine and shallow-marine environments patterns of erosion and sediment accumulation, and hence the development of unconformities, are controlled largely by two interrelated factors. These are changes in depositional base level, a hypothetical surface asymptotic approximately to sea level (or lake level), and above which significant sediment accumulation is not possible (Barrell, 1917; Mackin, 1948; Wheeler, 1964; Leopold and Bull, 1979; Ross, 1990); and sediment supply or production. Such factors as variations in the grain size and cohesion of available terrigenous sediment, the water temperature, salinity, oxygen content and availability of nutrients at sites of carbonate accumulation, river discharge, the direction and strength of marine 
currents, water depth and depth to wave base, and the geometry of the depositional surface also influence patterns of sedimentation, and they may be important in the development of small-scale sedimentary cyclicity. However, they are probably not by themselves responsible for the existence of most unconformity-bounded depositional sequences, and are not considered further here.

The elevation of base level at a particular locality is primarily a function of the rates of change of subsidence and eustatic sea level, but is influenced also by sediment supply. By definition, points at base level are subject to sediment bypassing, and those above base level, to erosion. Expansion of the zone of bypassing (and the development of offlap) is therefore promoted by a decrease in the rate of subsidence and by an increase in the rate of eustatic fall; and erosion surfaces tend to become buried (onlap) when the rate of subsidence increases or the rate of eustatic fall decreases (or sea level is rising). Sediment supply influences both the configuration of topographic profiles and shoreline position, which itself affects the elevation of depositional base level at a given point landward of the shoreline. From a qualitative point of view, changes in sediment supply would therefore be expected to influence the landward as well as the seaward extent of sediment accumulation at any given time. Under conditions of constant subsidence rate and constant rate of eustatic fall, regression due to an increase in sediment supply would be accompanied by progressive onlap as rivers graded to higher elevations, and transgression due to a decrease in sediment supply would be accompanied by offlap.

Several obvious feedbacks are involved here. For example, changes in depositional base level themselves influence sediment supply through the effects of locally enhanced erosion or storage of sediment. Shoreline variations induced by changes in depositional base level therefore result in a negative feedback on base-level change. Sediment accumulation also produces a load, which tends to augment tectonically driven subsidence, and hence to increase the amount of space available for additional sedimentation. However, to the extent that loads are accommodated by flexure of the lithosphere rather than by local isostatic com- pensation, this feedback is more complicated because sedimentation in one part of the basin may lead to either a decrease or an increase in the rate of subsidence in adjacent areas (Watts and Thorne, 1984; Reynolds et al., 1990). The space available for sedimentation during a given time increment is also influenced by the effects of compaction and in some cases by deformation of existing sediments through diapirism and detached faulting.

To quantify these considerations is difficult. Not only are the feedbacks involved poorly understood but the response of the depositional system to any perturbation is time-dependent, and the perturbations are themselves both time-dependent and operative at a broad range of frequencies. Static equilibrium conditions seldom exist. For these reasons, the task of isolating any of the variables in the real world is daunting: there are simply too many degrees of freedom.

\section{Quantitative considerations}

The most sensible way of accommodating the many uncertainties in a quantitative model is to make some reasonable first-order assumptions, and then to consider the sensitivity of the conclusions to specific factors not initially included. Of course, the successful reproduction of specific features of observed stratigraphy does not guarantee that all or even any of the most important parameters have been included. For example, most basinfilling models generate onlap-offlap cycles, but few focus specifically on the origin of the unconformities between depositional sequences.

A point of departure for this paper is an analysis by Thorne and Watts (1984) of the conditions for the formation of unconformities in predominantly siliciclastic sediments in passive continental margins. The tectonic subsidence $(Y)$ of a basin can be written (modified from Steckler and Watts, 1982):

$$
Y=\Phi * S^{*}\left[\frac{\rho_{\mathrm{m}}-\rho_{\mathrm{s}}}{\rho_{\mathrm{m}}-\rho_{\mathrm{w}}}+\Delta_{\mathrm{SL}} \frac{\rho_{\mathrm{w}}}{\rho_{\mathrm{m}}-\rho_{\mathrm{w}}}\right]+W_{\mathrm{d}}+\Delta_{\mathrm{SL}}
$$

where $S^{*}$ is the change in sediment thickness corrected for the effects of compaction; $\Delta_{\mathbf{S L}}$ is the 
eustatic change during the interval of sedimentation (positive downwards, following the sign convention of Thorne and Watts, 1984); $W_{\mathrm{d}}$ is the water depth at the end of the same interval; $\rho_{\mathrm{m}}$, $\rho_{\mathrm{s}}$, and $\rho_{\mathrm{w}}$ are the densities of mantle, sediment and water, and $\Phi$ is the basement response function relating sediment and water loads to tectonic subsidence through convolution (indicated by *). Note that $\rho_{\mathrm{m}}$ and $\rho_{\mathrm{w}}$ are to a first approximation constants but that $\rho_{\mathrm{s}}$ gradually changes with time as the sediment becomes lithified. The values of $W_{\mathrm{d}}$ and $S^{*}$ also vary spatially as well as with time. To simplify the discussion, we assume local isostatic compensation, and eqn. (1) becomes:

$Y=S^{*} \frac{\rho_{\mathrm{m}}-\rho_{\mathrm{s}}}{\rho_{\mathrm{m}}-\rho_{\mathrm{w}}}+W_{\mathrm{d}}+\Delta_{\mathrm{SL}} \frac{\rho_{\mathrm{m}}}{\rho_{\mathrm{m}}-\rho_{\mathrm{w}}}$

A visual representation of this relation is given in Fig.6A. In considering the origin of subaerial unconformities, we are interested primarily in sites located above sea level, not ones below sea level. For a point above sea level, eqn. (2) must be modified to correct for the sediment load above the datum, resulting in the somewhat less familiar relation (Fig.6B):

$Y=S^{*} \frac{\rho_{\mathrm{m}}-\rho_{\mathrm{s}}}{\rho_{\mathrm{m}}-\rho_{\mathrm{w}}}+\left(h+\Delta_{\mathrm{SL}}\right) \frac{\rho_{\mathrm{m}}}{\rho_{\mathrm{m}}-\rho_{\mathrm{w}}}$

where $h$ is the elevation of the sediment surface with respect to sea level (positive downwards), and like $W_{d}$ varies in both space and time. The term $h$ is defined in this way to make it exactly equivalent to and of the same sign as $W_{\mathrm{d}}$. By taking the time derivative, we obtain an expression for the rate of tectonic subsidence $(\dot{Y})$ :

$$
\dot{Y}=\dot{S}^{*} \frac{\rho_{\mathrm{m}}-\rho_{\mathrm{s}}}{\rho_{\mathrm{m}}-\rho_{\mathrm{w}}}-S^{*} \frac{\dot{\rho}_{\mathrm{s}}}{\rho_{\mathrm{m}}-\rho_{\mathrm{w}}}+\left(\dot{h}+\Delta_{\mathrm{SL}}\right) \frac{\rho_{\mathrm{m}}}{\rho_{\mathrm{m}}-\rho_{\mathrm{w}}}
$$

\section{A PoInts below SeA LeVEL \\ B POINTS ABOVE SEA LEVEL
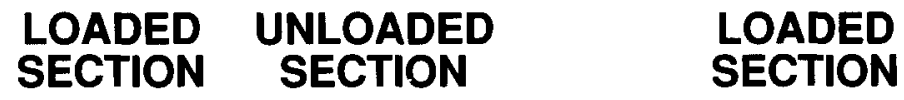 \\ UNLOADED SECTION}

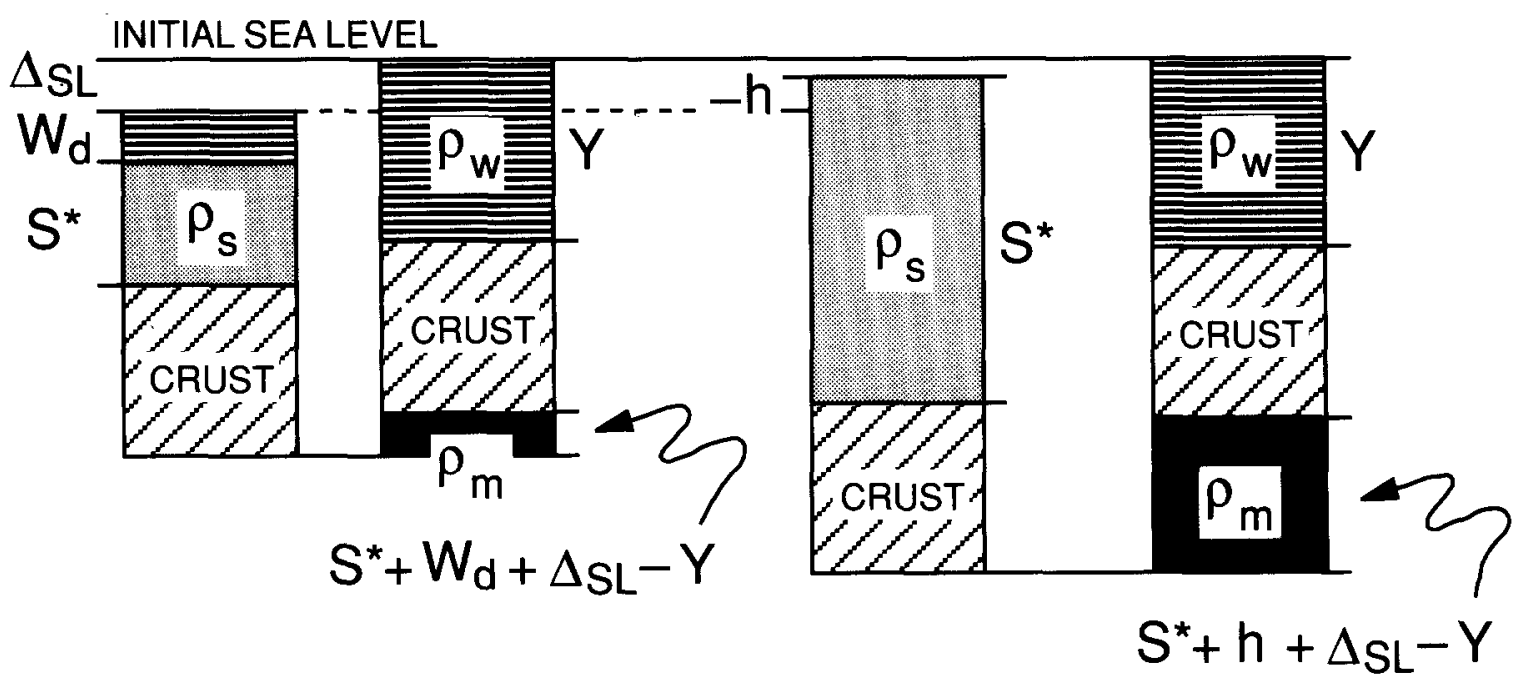

Fig.6. Derivation of tectonic subsidence $(Y)$ for sedimentation below (A) and above sea level (B), assuming local isostatic compensation and that the base of the sedimentary column was initially at sea level. Tectonic subsidence is the subsidence that would take place in water in the absence of sedimentation and eustatic change. Simple balancing of "loaded" and "unloaded" columns leads to eqn. (2) and (3) (see text). Other abbreviations: $S^{*}=$ change in sediment thickness corrected for the effects of compaction; $\Delta_{\mathrm{SL}}=$ eustatic change during the interval of sedimentation (positive downwards); $W_{\mathrm{d}}=$ water depth at the end of the same interval (case A); $h=$ elevation of the sediment surface with respect to sea level (positive downwards, case B); $\rho_{\mathrm{m}}, \rho_{\mathrm{s}}$, and $\rho_{\mathrm{w}}=$ densities of mantle, sediment and water. 
where $\dot{S}^{*}$ is the rate of increase in sedimentary thickness, corrected for compaction; $\dot{h}$ is the rate of decrease of elevation with respect to sea level; $\Delta_{\mathrm{SL}}$ is the rate of eustatic fall; and $\dot{\rho}_{\mathrm{s}}$ is the rate of increase in the density of the sediments. $\rho_{\mathrm{s}}$ varies slowly with time, especially when the total thickness of sediment deposited is large, and more important, $\dot{\rho}_{\mathrm{s}}$ is approximately constant for short intervals. The second term on the right side of eqn. (4) is therefore both small and constant for short intervals, and for the purpose of this analysis eqn. (4) may be approximated as:

$\dot{Y}=\dot{S}^{*} \frac{\rho_{\mathrm{m}}-\rho_{\mathrm{s}}}{\rho_{\mathrm{m}}-\rho_{\mathrm{w}}}+\left(\dot{h}+\Delta_{\mathrm{SL}}\right) \frac{\rho_{\mathrm{m}}}{\rho_{\mathrm{m}}-\rho_{\mathrm{w}}}$

\section{Line of critical bypassing}

The line of critical bypassing is defined here as an imaginary line on the earth's surface separating zones of bypassing and/or erosion from zones of sediment accumulation $\left(L_{\mathrm{c}}\right.$ in Fig.7). By critical, I mean that only a small change in equilibrium conditions or a small increment of time is required for sites of bypassing and/or erosion near the line to become ones of sedimentation, and vice-versa. The stratigraphic record of lateral shifts in the location of critical bypassing is onlap and offlap (Fig.7B and C), and indeed lateral variations in the distribution of erosion, bypassing and sediment accumulation are implicit in these terms. However, the concept of critical bypassing emphasizes the genetic relation between onlap and offlap, and more important it takes into account the effects of post-depositional erosion. The instantaneous point of offlap for a given horizon in a given profile is commonly not preserved.

The position of the line of critical bypassing is typically landward of the shoreline, and independent of it. That is, although both features may migrate as a result of changes in depositional base level or sediment supply, and in this sense they are related, they do not necessarily migrate at the same rate or even in the same direction (cf. Pitman, 1978; Pitman and Golovchenko, 1983; Angevine, 1989; Reynolds et al., 1990). For example, early highstand deposition is associated with progressive stratal onlap and with overall regression of the

\section{LINE OF CRITICAL BYPASSING $\left(L_{c}\right)$}
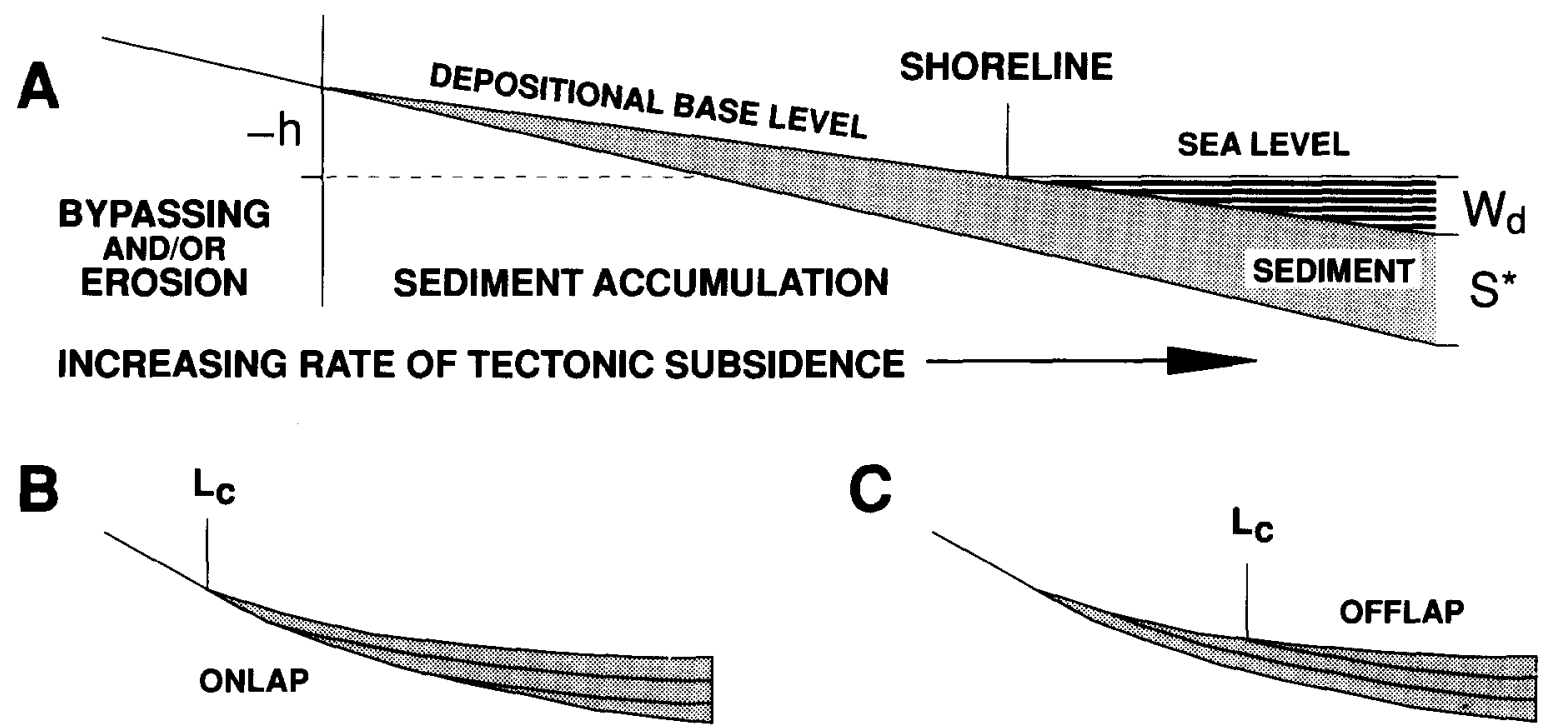

Fig.7. (A) Cross section illustrating the definition of the line of critical bypassing (a point in two dimensions), which at any instant separates zones of bypassing and/or erosion from zones of sediment accumulation. Abbreviations: $h=$ elevation of the sediment surface with respect to sea level (positive downwards); $W_{\mathrm{d}}=$ water depth; $S^{*}=$ incremental aggradation of the sediment surface corrected for the effects of compaction. Each of these terms varies in both space and time. (B and $C$ ) The development of onlap (B) and offlap (C) by lateral migration of the line of critical bypassing, shown here for the youngest increment of sediment. 
shoreline (Fig.1), and the development of a type 1 sequence boundary (involving subaerial exposure of marine sediments) requires the line of critical bypassing to "catch up" with the regressing shoreline during the late highstand. An exception is the case in which little or no sediment is transferred across the shoreline: all sediment is either produced in situ or brought laterally along the shelf (e.g., some carbonate platforms), and under those conditions the line of critical bypassing is more or less coincident with the shoreline.

At the line of critical bypassing ( $L_{\mathrm{c}}$ in Fig.7), $\dot{S}^{*}=0$ by definition, and:

$$
\dot{Y}_{\mathrm{LC}}=\left(\dot{h}_{\mathrm{LC}}+\dot{\Delta}_{\mathrm{SL}}\right) \frac{\rho_{\mathrm{m}}}{\rho_{\mathrm{m}}-\rho_{\mathrm{w}}}
$$

where the $\dot{Y}_{L C}$ and $\dot{h}_{L C}$ refer to the values of $\dot{Y}$ and $\dot{h}$ at $L_{\mathrm{c}}$. The term $\dot{h}$ is in general non-zero, and landward of $L_{\mathrm{c}}$ assumes a value that depends in part on the rate of erosion. Basinward of $L_{\mathrm{c}}, \dot{h}$ is sensitive to geographic changes in shoreline position, as well as to changes in the shape of the depositional profile. For a profile that changes position but not its overall shape with respect to the shoreline (a steady-state profile of Thorne and Swift, 1990), $\dot{h}>0$ for transgression, and $\dot{h}<0$ for regression. For a profile that is graded to a stationary shoreline (an isostatic equilibrium profile of Thorne and Swift, 1990), $\dot{h}=0$ at all points between $L_{\mathrm{c}}$ and the shoreline.

The concept of a line of critical bypassing differs from that of an equilibrium point, which is defined by Posamentier et al. (1988) as a point on a given profile at which the rate of eustatic fall equals the rate of subsidence of a stratigraphic datum located at or above the top of the basement. By subsidence, these authors appear to mean the total subsidence during some increment of time, including that due to sediment loading and to compaction of any sediment beneath the datum (H.W. Posamentier, pers. commun., 1990). At an equilibrium point, the stratigraphic datum is by definition stationary with respect to the sea surface, and in terms of the parameters used in this paper, this is equivalent to $\dot{S}^{*}+\dot{h}=0$ or to $\dot{S}^{*}+\dot{W}_{\mathrm{d}}=0$, depending on whether the depositional surface is above or below sea level. Eustasy does not enter into either relation because in this case subsidence is measured with respect to the sea surface not the centre of the earth. An alternative way of defining an equilibrium point would be to refer eustasy to the rate of tectonic subsidence, with a correction for the water load. In this case, the equilibrium point would be given by:

$$
\dot{S}^{*} \frac{\rho_{\mathrm{m}}-\rho_{\mathrm{s}}}{\rho_{\mathrm{m}}}+\dot{h}=0
$$

or

$\dot{S}^{*} \frac{\rho_{\mathrm{m}}-\rho_{\mathrm{s}}}{\rho_{\mathrm{m}}-\rho_{\mathrm{w}}}+\dot{W}_{\mathrm{d}}=0$

These expressions allow artificial distinctions between "marine" and "subaerial" accommodation (Posamentier et al., 1988; Posamentier and Vail, 1988) to be rationalized, and they are equivalent to the definition of critical bypassing (eqn. 6) when $\dot{h}_{L \mathrm{C}}=0$.

\section{Limits to accommodation}

The concept of accommodation refers to the space made available for potential sediment accumulation (Jervey, 1988; Posamentier et al., 1988). As a first approximation, we can think of accommodation as some function of relative sea-level change (Posamentier et al., 1988), but in order to specify it quantitatively we need to constrain the elevation term $\dot{h}$ in eqn. (5) and (6). An imaginative way of accounting for variations in elevation has been suggested by Flemings and Jordan (1989) and Jordan and Flemings (1990). Following studies by Kenyon and Turcotte (1985), they assume that erosion and sediment transport are approximated by slope-controlled diffusion, and that sediment transport is proportional to surface gradient. This leads to the relation:

$\dot{h}_{0}=K \frac{\partial^{2} h_{0}}{\partial x^{2}}$

in which $\dot{h}_{0}$ is the rate of change of elevation with respect to a fixed datum (positive upwards), $K$ is a transportation coefficient with units of length ${ }^{2} /$ time, and $x$ is horizontal position. The degree to 
which the depositional surface aggrades or degrades $\left(\dot{h}_{0}>0\right.$ or $\dot{h}_{0}<0$, respectively) depends on the local curvature of the slope (a profile that is concave upwards has positive curvature). Local topography is smoothed with time, and in the Flemings and Jordan model clinoforms are produced in the marine environment by assuming that marine sediment transport is less efficient than non-marine transport.

Since $\dot{h}_{0}=-\left(\dot{h}+\Delta_{\mathrm{SL}}\right)$, eqn. (8) can be written:

$\dot{h}+\Delta_{\mathrm{SL}}=K \frac{\partial^{2} h}{\partial x^{2}}$

where negative curvature corresponds with a slope that is concave upwards. At each point along the profile, substituting in eqn. (5):

$\dot{Y}=\dot{S}^{*} \frac{\rho_{\mathrm{m}}-\rho_{\mathrm{s}}}{\rho_{\mathrm{m}}-\rho_{\mathrm{w}}}+\frac{\rho_{\mathrm{m}}}{\rho_{\mathrm{m}}-\rho_{\mathrm{w}}} K \frac{\partial^{2} h}{\partial x^{2}}$

and at the line of critical bypassing $\left(x=x_{\mathrm{LC}}\right)$, substituting in eqn. (6):

$\dot{Y}_{L \mathrm{C}}=\frac{\rho_{\mathrm{m}}}{\rho_{\mathrm{m}}-\rho_{\mathrm{w}}} K \frac{\partial^{2} h}{\partial x^{2}}\left(x=x_{\mathrm{LC}}\right)$

In the light of these considerations, under what conditions do unconformities develop? Here we consider the influence of changes in sediment supply and of changes in the rate of eustatic fall or rate of tectonic subsidence.

\section{Changes in rate of sediment supply}

We begin by assuming an isostatic equilibrium profile (Thorne and Swift, 1990), a constant rate of sediment supply, a constant rate of eustatic fall, and that the rate tectonic subsidence is constant at each point along the profile but increases in a basinward direction (Fig.8). The initial position of the line of critical bypassing is $L_{\mathrm{c}}$, and $\dot{h}_{\mathrm{LC}}=0$ (eqn. 6). An increase in the rate of sediment supply leads to regression of the shoreline (Fig.8A). Dynamic equilibrium can be maintained by gradual aggradation of the alluvial profile $(\dot{h}<0$ at all points), and by a concomitant shift of the line of critical bypassing towards $L_{\mathrm{c}}^{\prime}$ where the rate of tectonic subsidence is smaller. The line of critical bypassing is unlikely to remain at its initial position

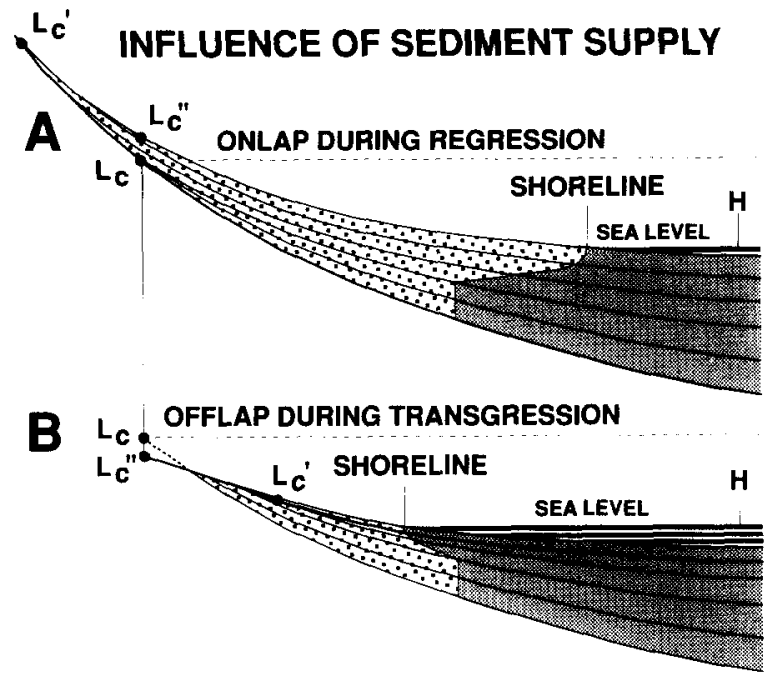

Fig.8. Cross sections illustrating the influence of sediment supply on the location of the line of critical bypassing $\left(L_{\mathrm{c}}\right)$. Bold lines are sequence boundaries, and fine lines are other time surfaces. Initial conditions are an isostatic equilibrium profile ( $\dot{h}=0$ at all points between $L_{\mathfrak{c}}$ and the shoreline; Thorne and Swift, 1990), a constant rate of sediment supply, a constant rate of eustatic fall, and a rate of tectonic subsidence that is constant at each point along the profile but increases in a basinward direction. After two time increments, in (A) there is an abrupt increase in sediment supply leading to regression of the shoreline, and in (B), an abrupt decrease in sediment supply leading to transgression. In each case, the line of critical bypassing migrates to $L_{\mathfrak{c}}{ }^{\prime}$. As a new isostatic equilibrium profile is established, and under conditions of local isostatic compensation, the line of critical bypassing tends to return to its initial geographic position $\left(L_{\mathrm{c}}{ }^{\prime \prime}\right)$, but at a different elevation (higher in A, lower in B). The elevation of $L_{\mathrm{c}}(H)$ is initially fixed with respect to sea level, and the loading due to the sediment column between $L_{\mathrm{c}}$ and $L_{\mathrm{c}}{ }^{\prime \prime}$ is not shown.

because this would lead to a reduction in the gradient of a depositional profile (the elevation of $L_{\mathrm{c}}$ is fixed with respect to sea level when $\dot{h}_{L \mathrm{C}}=0$ ). Indeed, an increase in sediment flux would favour a steeper profile (Snow and Slingerland (1987), and eqn. (10) above). Similarly, assuming the same initial conditions, a decrease in the rate of sediment supply leads to transgression of the shoreline (Fig.8B). Dynamic equilibrium can again be maintained by a gradual lowering of the alluvial profile ( $\dot{h}>0$ at all points), and by a downward shift of the line of critical bypassing towards $L_{\mathrm{c}}{ }^{\prime}$ where the rate of tectonic subsidence is larger. Note that this is not necessarily accomplished by erosion, but 
through a decrease in the rate of sediment accumulation along the profile.

In the process of establishing a new isostatic equilibrium profile ( $\dot{h}=0$ at all points), the line of critical bypassing tends to return to its initial geographic position controlled by the relative magnitudes of $\Delta_{\mathrm{sL}}$ and $\dot{Y}$ (eqn. 6). Only its elevation is different $\left(L_{\mathrm{c}}{ }^{\prime \prime}\right.$ in Fig.8). Under conditions of constant sediment supply, the geographic location of the line of critical bypassing therefore appears to be less sensitive to sediment supply than is the location of the shoreline. The situation is somewhat more complex in the case of flexural isostasy because the rate of subsidence at the point of onlap is influenced by the rate at which the adjacent sedimentary load increases. That is, the rate of subsidence at a given point is not entirely of tectonic origin even when the rate of sediment accumulation at that point is zero.

These conclusions are consistent with available geomorphological literature (reviewed by Posamentier and Vail, 1988), and indicate that small shifts in the position of onlap (type 2 sequence boundaries) can be produced by changes in sediment input without changing either $\dot{\Delta}_{\mathrm{SL}}$ or $\dot{Y}$. Type 2 boundaries account for $59 \%$ of the 118 Mesozoic and Cenozoic unconformities identified by Haq et al. $(1987,1988)$ as global sequence boundaries, and more attention needs to be paid to the influence of sediment supply on the origin of these features. In contrast, type 1 sequence boundaries require the lowering of depositional base level seaward of the shoreline, and cannot be explained in this way.

\section{Changes in rate of eustatic fall or rate of tectonic subsidence}

To illustrate the role of eustasy and tectonic subsidence in the origin of unconformities, we assume an isostatic equilibrium profile and a constant rate of sediment supply (Fig.9A). As before, the initial position of the line of critical bypassing is $L_{\mathrm{c}}$, and $\dot{h}_{L \mathrm{C}}=0$. A small but instantaneous increase in the rate of sea-level fall results in gradual offlap towards a new line of critical bypassing (at $L_{\mathrm{c}}{ }^{\prime}$ in Fig.9B), for which the rate of tectonic subsidence is correspondingly greater than at $L_{\mathrm{c}}$

\section{INFLUENCE OF EUSTASY}

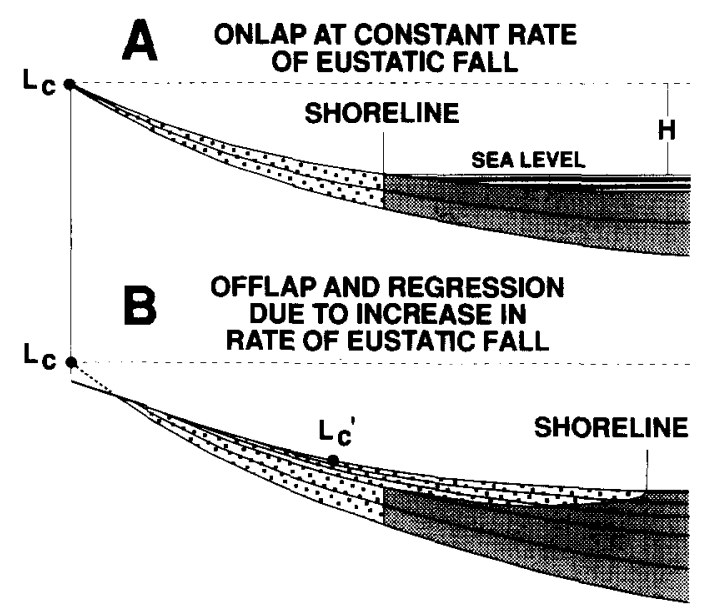

Fig.9. Cross sections illustrating the influence of eustasy on the location of the line of critical bypassing $\left(L_{\mathrm{c}}\right)$. Fine lines are time surfaces. Initial conditions (A) are as in Fig.8. The elevation of $L_{\mathrm{c}}(H)$ is initially fixed with respect to sea level. After two time increments (B), there is an abrupt increase in the rate of eustatic fall, leading to the onset of regression and migration of the line of critical bypassing towards a new equilibrium position $\left(L_{\mathrm{c}}{ }^{\prime}\right)$.

(eqn. 6). All points landward of the shoreline are immediately subject to relative uplift with respect to the sea surface $(\dot{h}<0)$, and dynamic equilibrium is maintained by a gradual decrease in the rate of sediment accumulation as a new isostatic equilibrium profile is achieved ( $\dot{h}=0$ again at all points). The position of onlap does not shift instantaneously to $L_{c}^{\prime}$ (as implied by Christie-Blick et al., 1990) because the location of the line of critical bypassing is subject to the negative feedback related to the onset of shoreline regression (discussed above), an effect which depends on the rate of regression and is not readily quantifiable. However, it is not possible without an increase in sediment supply for the line of critical bypassing to migrate in a landward direction (as in Fig.8A) because a feedback can change only the rate at which equilibrium is achieved and not the direction of the equilibrium shift.

An important conclusion is that the downward shift in coastal onlap from $L_{\mathrm{c}}$ to $L_{\mathrm{c}}{ }^{\prime}$ is primarily a response to an increase in the rate of eustatic fall (see also Reynolds et al., 1990), rather than to the magnitude of fall during the time interval 
involved. Hence, the distance between $L_{\mathrm{c}}$ and $L_{\mathrm{c}}{ }^{\prime}$, no matter how it is measured, in general provides no direct information about the amplitude of sealevel change, contrary to the method originally proposed by Vail et al. (1977) for measuring eustatic falls from seismic stratigraphy. Relatively large shifts in the position of onlap can also be achieved at modest rates of eustatic change, rates that are on the same order as typical rates of tectonic subsidence $(<1 \mathrm{~cm} / 1000 \mathrm{yrs}$; eqn. 6$)$. Rapid eustatic falls with amplitudes of as much as $100 \mathrm{~m}$, inferred for the development of some type 1 unconformities during times of minimal continental ice cover such as the Cretaceous (Haq et al., 1987, 1988), are neither indicated by available data (Christie-Blick et al., 1990) nor likely in the context of this analysis.

A corollary is that a downward shift in coastal onlap may be achieved equally well by either an increase in the rate of eustatic fall or a decrease in the rate of tectonic subsidence, and that there is nothing inherently eustatic about onlap-offlap cycles. As a simplification, it is commonly assumed that tectonic subsidence varies only on long time scales (>10 m.y.), and that high-frequency oscillations of relative sea level are of eustatic origin (e.g., Haq et al., 1987). This is a reasonable working hypothesis, but one that has not yet been adequately tested against geological data. Cloetingh et al. (1985, and several subsequent articles) and Karner (1986) have proposed from theoretical studies that variations in the horizontal stresses within the lithosphere can induce vertical motions of tens of metres, at rates comparable to typical rates of tectonic subsidence. There appear to be a number of difficulties with this mechanism that cast doubt on its relevance to the origin of unconformity-bounded sequences (Christie-Blick et al., 1990; G.D. Karner, pers. commun., 1990), but other tectonic mechanisms for short-term sea-level change may yet be discovered, and it is premature to assume that eustatic and tectonic controls on sea level may be distinguished simply on the basis of frequency. On the other hand, evidence in a given basin for crustal deformation coeval with the development of a sequence boundary is not sufficient to demonstrate that the unconformity is of tectonic origin (e.g., Hubbard, 1988) because unconformities of eustatic origin may be enhanced by tectonic activity (Vail et al., 1984). In other words, the origin of the observed stratal geometry needs to be distinguished from the ultimate control of the timing of the unconformity.

\section{Rapid eustatic change}

The formation of prominent sequence boundaries does not require rapid or large changes in eustatic sea level, but in some cases eustatic changes are both rapid and of high amplitude. For example, there have been several times in earth history when appreciable areas of the continents were covered by glacial ice: the Neogene, PermoCarboniferous, late Devonian, late Ordovician to early Silurian, and at several times in the Proterozoic (Hambrey and Harland, 1981). During those times, sea level is likely to have fluctuated by several tens of metres and at rates several orders of magnitude faster than typical rates of tectonic subsidence (Pitman and Golovchenko, 1983; Gornitz and Lebedeff, 1987). Climatically induced variations in lake level in closed depositional basins, such as those of Triassic-Jurassic age in eastern Noth America (Olsen, 1986), and the late Miocene Messinian crisis of the Mediterranean (Cita, 1982) are similarly examples of large and rapid changes in depositional base level. Under such conditions, the rate of tectonic subsidence is effectively zero, and to a first approximation, changes in elevation or water depth at a given site are related directly to the amplitude of eustatic change (or local change in base level) and to the thickness of accumulated sediment (eqn. 2 and 3 ).

\section{Onlap related to eustatic rise and time of maximum onlap}

During times of eustatic rise, the location of the line of critical bypassing, and hence of coastal and non-marine onlap, is controlled by relict topography and the sediment supply. This is because the term $\dot{h}$ in eqn. (6) is positive (decreasing elevation) even for points at which the rate of subsidence is zero. Onlap continues after the time of maximum flooding because $\dot{h}$ is then negative at the shoreline (regression), and excess accommodation is therefore available (see Fig.8A). For oscillatory sea- 
level change, the time of maximum onlap is thought to correspond to falling eustatic sea level $\left(\Delta_{\mathrm{SL}}>0\right)$ when the value of $\dot{h}$ at the line of critical bypassing $\left(\dot{h}_{L \mathrm{C}}\right)$ is also negative and approximately equal to $\dot{h}$ at the shoreline (an approximation to a steady-state profile of Thorne and Swift, 1990). Any additional increase in the rate of eustatic fall would tend to oversteepen the depositional profile, and hence lead to offlap. This is because $\dot{h}_{L C}$ eventually becomes increasingly negative more rapidly than does $\dot{h}$ at the shoreline (see Fig.9). If this reasoning is correct, the time of transition from onlap to offlap is influenced by the rate of regression, and hence by sediment supply, with largest lags with respect to the eustatic high stand favoured where sediment is most abundant.

A markedly different interpretation of sequenceboundary development is evident in the widely referenced conceptual cross sections of Vail (1987), and discussed at length by Posamentier et al. (1988) and Posamentier and Vail (1988). According to these authors, deposition of the highstand fluvial wedge is a response to rapid progradation during a time of increasingly rapid eustatic fall, and maximum onlap is virtually synchronous with the development of the sequence boundary. Two difficulties with this model are as follows. First, it requires the line of critical bypassing to move landward while the rate of eustatic fall increases to its maximum value. I have shown above that this is possible only if the sediment supply is progressively increased. Second, the Posamentier et al. model does not explain offlap, and it supplies no compelling explanation for the supposedly abrupt downward shift in onlap observed at sequence boundaries. For these reasons, it seems more likely that rapid highstand progradation is a response to offlap and that the fluvial wedge develops preferentially during early not late highstand deposition (see Fig.1).

\section{Timing of sequence boundaries}

There is general agreement that sequence boundaries tend to form during times of accelerated eustatic fall or during times of reduced rate of tectonic subsidence, and that if sea level is actually rising, uplift at a rate exceeding the rate of eustatic rise is required for a sequence boundary to develop. Beyond the unresolved issue of the role of tectonics in the formation of unconformities are questions concerning the exact relation between the timing of unconformities and eustatic oscillations. In particular, to what extent do eustatic sequence boundaries correspond to times of maximum rate of sealevel fall (inflection points on the eustatic curve; Jervey, 1988; Posamentier et al., 1988), and to what extent are leads or lags involved (Posamentier and Vail, 1988; Christie-Blick et al., 1990; Jordan and Flemings, 1990; Reynolds et al., 1990)? No data are yet available to evaluate this problem, but it is central to a good deal of activity currently aimed at testing the idea that sedimentary cyclicity is dominated by eustasy (e.g., Haq et al., 1987, 1988), and in which it is assumed that sequence boundaries of eustatic origin should be of nearly the same age in all marine basins (Christie-Blick, 1990; Watkins and Mountain, 1990). If it is determined by means of very high-resolution geochronology that prominent sequence boundaries of approximately the same age in two widely separated basins are in fact of measurably different age, how great a discrepancy will be required for us to conclude that the boundaries are not after all eustatic?

Two recent papers shed some light on the issue of leads and lags. Using a diffusion model for erosion and sediment transport across a passive continental margin, Jordan and Flemings (1990) concluded that sequence boundaries may range in age from the time of most rapid eustatic fall typically to about $\frac{1}{8}$ cycle later, and in some cases to as much as $\frac{1}{4}$ cycle later. A lag is favoured by inefficient non-marine transport, slow subsidence, large sediment flux and sea-level changes that are either of high frequency or high amplitude. Jordan and Flemings (1990) make very simple assumptions about passive-margin subsidence (approximated as a rotating rigid beam), and they do not incorporate isostasy or compaction. Moreover, nearly all of their results refer to type 2 sequence boundaries. Further development and testing are therefore needed, especially to simulate type 1 boundaries, and to evaluate the sensitivity of the conclusions to such factors as isostasy and compaction. It would also be useful to explore the possibility that 
the transportation coefficient in a given environment might vary, perhaps as a function of slope or according to whether sea level is rising or falling.

A very different passive-margin model has been developed by Reynolds et al. (1990) to investigate the influence of flexural isostasy and compaction on the formation of unconformity-bounded sequences. Tectonic subsidence is represented by a hinged platform tilting at a constant rate, but in this case the depositional surface is maintained as two segments, a horizontal shelf with zero water depth, and a slope of fixed gradient. Type 1 unconformities are favoured under conditions of low sediment supply and/or low tectonic-subsidence rate, and for eustatic fluctuations that are rapid and/or of high amplitude. In the simplest case, in which isostatic effects are ignored (infinite flexural rigidity), type 2 sequence boundaries correspond to inflection points in the eustatic curve. Type 1 sequence boundaries tend to predate the time of most rapid fall by as much as $\frac{1}{4}$ cycle, although again typically less than this. The effect of both isostatic compensation and compaction is to introduce time delays in the development of sequence boundaries, and to promote the generation of type 2 boundaries. Overall, the model is highly sensitive to sea-level change and generates type 1 unconformities at times of relatively slow eustatic fall owing to the assumption of a shelf fixed at sea level. Phase leads predicted for type 1 unconformities are likely to be overestimated for the same reason. An important extension of this model therefore would be to investigate the sensitivity of the conclusions to the inclusion of onlap in subaerial environments, along the lines suggested in this paper.

In these two models, we have a number of conditions and processes that may cause the timing of sequence boundaries in siliciclastic sediments either to predate or to postdate the time of most rapid eustatic fall, perhaps by as much as $\frac{1}{4}$ cycle. From a qualitative perspective, leads and lags of equivalent duration would be expected also in carbonate sediments. Carbonate sediments accumulate subaerially only insofar as they are transported landward by the action of storms and the wind, and for this reason the line of critical bypassing may be close to sea level, as in the Reynolds et al. model. Carbonate accumulation rates tend to be high, and type 2 sequence boundaries with associated time lags of the sort modelled by Reynolds et al. (1990) would therefore be expected in ramp settings with high rates of tectonic subsidence. On the other hand, carbonate platforms are easily exposed during eustatic falls because they tend to build to sea level (Kendall and Schlager, 1981), and type 1 boundaries with well developed lowstands would be expected where rates of subsidence are low, platform margins are comparatively steep and where there is a ready supply of terrigenous sediment. As in siliciclastic sediments, type 1 boundaries in carbonate environments would be expected to predate the time of most rapid sealevel fall, and perhaps to a greater degree.

In the case of a given sequence boundary, the net lead or lag is likely to be due to a combination of factors. These factors may vary within a single basin, and certainly from one basin to another. This leads to the conclusion that a sequence boundary, as it is objectively identified in a basin, may not after all be a single physical surface, but rather a series of closely spaced surfaces that in different places have similar geometrical attributes (onlap, offlap and downlap) and similar relations with respect to sedimentary facies. An obvious test of the models is to attempt to measure leads and lags directly, for example in the Neogene, a time for which high-resolution geochronology is possible and the glacial-eustatic record is relatively well established (Miller et al., 1990). However, in order to evaluate the synchroneity of sequence boundaries, to test the notion that they are fundamentally of eustatic origin, it will be important to select basins for which rates of subsidence and sediment supply and sequence geometry are similar.

\section{Acknowledgements}

This paper represents an extension of ideas first developed for an article published by the U.S. National Academy of Sciences, and which itself evolved through many drafts over a span of more than five years as a result of numerous delays in publication. Essential elements were presented in 1989 at the Chapman Conference at Snowbird, Utah on the Causes and Consequences of Long- 
Term Sea Level Change, as well as at the International Geological Congress in Washington, D.C. I thank K.T. Biddle, P.B. Flemings, J. GarcíaMondéjar, C.G.St.C. Kendall, H.W. Posamentier, and M.S. Steckler for critical reviews that were very helpful in fine-tuning the arguments presented, as well as many other colleagues who over a period of several years have freely shared and vociferously defended their own views on the origin of unconformity-bounded depositional sequences. I also thank the vice-chancellor and the School of Earth Sciences at the Flinders University of South Australia for providing a thoroughly agreeable and disturbance-free environment in which to crystallize the manuscript during my sabbatical leave. The paper is a byproduct of research supported by National Science Foundation grants OCE 8600249 and OCE 89-11810 (Mountain, Miller and Christie-Blick), OCE 88-12509 (Karner and Christie-Blick) and EAR 89-17400 (Christie-Blick and Karner), by the Donors of the Petroleum Research Fund, administered by the American Chemical Society (PRF 16042-G2 and PRF 19989-AC2), and by the Arthur D. Storke Memorial Fund of the Department of Geological Sciences, Columbia University. It is also a contribution to the Global Sedimentary Geology Program on Cretaceous Resources, Events and Rhythms and represents Lamont-Doherty Geological Observatory Contribution No. 4752.

\section{References}

Ager, D.V., 1981. The Nature of the Stratigraphical Record. Wiley, New York, 2nd ed., 122 pp.

Aitken, J.D., 1978. Revised models for depositional Grand Cycles, Cambrian of the southern Rocky Mountains. Bull. Can. Pet. Geol., 26: 515-542.

Allen, P.A. and Homewood, P. (Editors), 1986. Foreland Basins. Int. Assoc. Sedimentol. Spec. Publ., 8: 453 pp.

Angevine, C.L., 1989. Relationship of eustatic oscillations to regressions and transgressions on passive continental margins. In: R.A. Price (Editor), Origin and Evolution of Sedimentary Basins and their Energy and Mineral Resources. Am. Geophys. Union Geophys. Monogr., 48: 29-35.

Bally, A.W. (Editor), 1987. Atlas of Seismic Stratigraphy. Am. Assoc. Pet. Geol. Stud. Geol., 27 (1): 124 pp.

Bally, A.W. (Editor), 1988. Atlas of Seismic Stratigraphy. Am. Assoc. Pet. Geol. Stud. Geol., 27 (2): 277 pp.

Bally, A.W. (Editor), 1989. Atlas of Seismic Stratigraphy. Am. Assoc. Pet. Geol. Stud. Geol., 27 (3): 244 pp.
Barrell, J., 1917. Rhythms and the measurement of geologic time. Geol. Soc. Am. Bull., 28: 745-904.

Baum, G.R. and Vail, P.R., 1988. Sequence stratigraphic concepts applied to Paleogene outcrops, Gulf and Atlantic basins. In: C.K. Wilgus, B.S. Hastings, C.G.St.C. Kendall, H.W. Posamentier, C.A. Ross, and J.C. Van Wagoner (Editors), Sea-Level Changes: An Integrated Approach. Soc. Econ. Paleontol. Mineral. Spec. Publ., 42: 309-327.

Berg, O.R. and Woolverton, D.G. (Editors), 1985. Seismic Stratigraphy II: An Integrated Approach to Hydrocarbon Exploration. Am. Assoc. Pet. Geol. Mem., 39: 276 pp.

Bosellini, A., 1984. Progradation geometries of carbonate platforms: examples from the Triassic of the Dolomites, northern Italy. Sedimentology, 31: 1-24.

Bosellini, A., 1988. Outcrop models for seismic stratigraphy: Examples from the Triassic of the Dolomites. In: A.W. Bally (Editor), Atlas of Seismic Stratigraphy. Am. Assoc. Pet. Geol. Stud. Geol., 27 (2): 194-203.

Brown, L.F., Jr. and Fisher, W.L., 1977. Seismic stratigraphic interpretation of depositional systems: Examples from the Brazilian rift and pull-apart basins. In: C.E. Payton (Editor), Seismic Stratigraphy - Applications to Hydrocarbon Exploration. Am. Assoc. Pet. Geol. Mem., 26: 213-248.

Burton, R., Kendall, C.G.St.C. and Lerche, I., 1987. Out of our depth: on the impossibility of fathoming eustasy from the stratigraphic record. Earth-Sci. Rev., 24: 237-277.

Butcher, S.W., 1989. The nickpoint concept and its implications regarding onlap to the stratigraphic record. In: T.A. Cross (Editor), Quantitative Dynamic Stratigraphy. Prentice-Hall, Englewood Cliffs, N.J., pp.375-385.

Christie-Blick, N., 1990. Sequence stratigraphy and sea-level changes in Cretaceous time. In: R.N. Ginsburg and B Beaudoin (Editors), Cretaceous Resources, Events and Rhythms. (NATO ASI Series C, Vol, 304.) Kluwer, Dordrecht, The Netherlands, pp.1-21

Christie-Blick, N. and Levy, M., 1989. Concepts of sequence stratigraphy, with examples from strata of Late Proterozoic and Cambrian age in the western United States. In: N. Christie-Blick and M. Levy (Editors), Late Proterozoic and Cambrian Tectonics, Sedimentation, and Record of Metazoan Radiation in the Western United States. 28th Int. Geol. Congr. Field Trip Guideb. T331. Am. Geophys. Union, Washington, D.C., pp.23-38.

Christie-Blick, N., Mountain, G.S. and Miller, K.G., 1988. Sea level history. Science, 241: 596.

Christie-Blick, N., Mountain, G.S. and Miller, K.G., 1990. Seismic stratigraphic record of sea-level change. In: Sea-level Change. (National Academy of Sciences Studies in Geophysics.) pp. 116-140.

Cita, M.B., 1982. The Messinian salinity crisis in the Mediterranean: A review. In: H. Berckhemer and $\mathrm{K}$. Hsü (Editors), Alpine-Mediterranean Geodynamics. Am. Geophys. Union, Geodyn. Ser., 7: 113-140.

Cloetingh, S., McQueen, H. and Lambeck, K., 1985. On a tectonic mechanism for regional sea-level variations. Earth Planet. Sci. Lett., 75: 157-166.

Demarest, J.M., II and Kraft, J.C., 1987. Stratigraphic record of Quaternary sea levels: Implications for more ancient strata. In: D. Nummedal, O.H. Pilkey and J.D. Howard 
(Editors), Sea-Level Fluctuation and Coastal Evolution. Soc. Econ. Paleontol. Mineral. Spec. Publ., 41: 223-239.

Dott, R.H., Jr., 1983. 1982 Presidential address: Episodic sedimentation - how normal is average? How rare is rare? Does it matter? J. Sediment. Petrol., 53: 5-23.

Eberli, G.P. and Ginsburg, R.N., 1989. Cenozoic progradation of northwestern Great Bahama Bank, a record of lateral platform growth and sea-level fluctuations. In: P.D. Crevello, J.L. Wilson, J.F. Sarg and J.F. Read (Editors), Controls on Carbonate Platform and Basin Development. Soc. Econ. Paleontol. Mineral. Spec. Publ., 44: 339-351.

Flemings, P.B. and Jordan, T.E., 1989. A synthetic stratigraphic model of foreland basin development. J. Geophys. Res., 94: 3851-3866.

Frazier, D.E., 1974. Depositional-episodes: their relationship to the Quaternary stratigraphic framework in the northwestern portion of the Gulf basin. Univ. Tex., Bur. Econ. Geol. Circ., 74-1: 27 pp.

Fulthorpe, C.S. and Carter, R.M., 1989. Test of seismic sequence methodology on a southern hemisphere passive margin: The Canterbury basin, New Zealand. Mar. Pet. Geol., 6: $348-359$.

Galloway, W.E., 1989. Genetic stratigraphic sequences in basin analysis I: Architecture and genesis of flooding-surface bounded depositional units. Am. Assoc. Pet. Geol. Bull., 73: $125-142$.

Garcia-Mondéjar, J. and Fernández-Mendiola, P.A., 1989. Evolución plataforma/cuenca en el Albiense de Lunada y Soba (Burgos y Cantabria). Secuencias, asociaciones de sistemas sedimentarios (systems tracts) y cambios del nivel del mar. XII Congr. Esp. Sedimentol., Libro-Guía Excursiones Geol., Excursión No. 1. Dep. Estratigr., Geodin. Paleontol. (Univ. País Vasco), and Div. Invest. Recursos (Ente Vasco de la Energía), Leioa-Bilbao, pp.7-43.

García-Mondéjar, J. and Fernández-Mendiola, P.A., 1991. Sequence stratigraphy and systems tracts of a mixed carbonate and siliciclastic platform-basin model: The Albian of Lunada and Soba, northern Spain. Am. Assoc. Pet. Geol. Bull., in prep.

Gornitz, V. and Lebedeff, S., 1987. Global sea-level changes during the past century. In: D. Nummedal, O.H. Pilkey and J.D. Howard (Editors), Sea-Level Fluctuation and Coastal Evolution. Soc. Econ. Paleontol. Mineral. Spec. Publ., 41: 3-16.

Greenlee, S.M., 1988. Tertiary depositional sequences, offshore New Jersey and Alabama. In: A.W. Bally (Editor), Atlas of Seismic Stratigraphy. Am. Assoc. Pet. Geol. Stud. Geol. 27 (2): 67-80.

Greenlee, S.M. and Moore, T.C., 1988. Recognition and interpretation of depositional sequences and calculation of sealevel changes from stratigraphic data - Offshore New Jersey and Alabama Tertiary. In: C.K. Wilgus, B.S. Hastings, C.G.St.C. Kendall, H.W. Posamentier, C.A. Ross and J.C. Van Wagoner (Editors), Sea-Level Changes: An Integrated Approach. Soc. Econ. Paleontol. Mineral. Spec. Publ., 42: 329-353.

Grotzinger, J.P., 1986. Cyclicity and paleoenvironmental dynamics, Rocknest platform, northwest Canada. Geol. Soc. Am. Bull., 97: 1208-1231.

Hambrey, M.J. and Harland, W.B. (Editors), 1981. Earth's
Pre-Pleistocene Glacial Record. Cambridge University Press, Cambridge, U.K., 1004 pp.

Haq, B.U., Hardenbol, J. and Vail, P.R., 1987. Chronology of fluctuating sea levels since the Triassic. Science, 235: 11561167.

Haq, B.U., Hardenbol, J. and Vail, P.R., 1988. Mesozoic and Cenozoic chronostratigraphy and cycles of sea-level change. In: C.K. Wilgus, B.S. Hastings, C.G.St.C. Kendall, H.W. Posamentier, C.A. Ross and J.C. Van Wagoner (Editors), Sea-Level Changes: An Integrated Approach. Soc. Econ. Paleontol. Mineral. Spec. Publ., 42: 71-108.

Helland-Hansen, W., Kendall, C.G.St.C., Lerche, I. and Nakayama, K., 1988. A simulation of continental basin margin sedimentation in response to crustal movements, eustatic sea level change, and sediment accumulation rates. Math. Geol., 20: $777-802$.

Hubbard, R.J., 1988. Age and significance of sequence boundaries on Jurassic and Early Cretaceous rifted continental margins. Am. Assoc. Pet. Geol. Bull., 72: 49-72.

International Subcommission on Stratigraphic Classification (Amos Salvador, Chairman), 1987. Unconformity-bounded stratigraphic units. Geol. Soc. Am. Bull., 98: 232-237.

James, D.P. and Leckie, D.A. (Editors), 1988. Sequences, Stratigraphy, Sedimentology: Surface and Subsurface. Can. Soc. Pet. Geol. Mem. 15, 586 pp.

James, N.P., 1984. Shallowing-upward sequences in carbonates. In: R.G. Walker (Editor), Facies Models. Geosci. Can. Reprint Ser. 1, 2nd ed., pp.213-228.

Jervey, M.T., 1988. Quantitative geological modelling of siliciclastic rock sequences and their seismic expression. In: C.K. Wilgus, B.S. Hastings, C.G.St.C. Kendall, H.W. Posamentier, C.A. Ross and J.C. Van Wagoner (Editors), Sea-Level Changes: An Integrated Approach. Soc. Econ. Paleontol. Mineral. Spec. Publ., 42: 47-69.

Johnson, J.G., 1987. Unconformity-bounded stratigraphic units: Discussion. Geol. Soc. Am. Bull., 99: 443.

Jordan, T.E. and Flemings, P.B., 1990. Large-scale stratigraphic architecture, eustatic variation, and unsteady tectonism: A theoretical evaluation. J. Geophys. Res., in press.

Karner, G.D., 1986. Effects of lithospheric in-plane stress on sedimentary basin stratigraphy. Tectonics, 5: 573-588.

Kendall, C.G.St.C. and Lerche, I., 1988. The rise and fall of eustasy. In: C.K. Wilgus, B.S. Hastings, C.G.St.C. Kendall, H.W. Posamentier, C.A. Ross and J.C. Van Wagoner (Editors), Sea-Level Changes: An Integrated Approach. Soc. Econ. Paleontol. Mineral. Spec. Publ., 42: 3-17.

Kendall, C.G.St.C. and Schlager, W., 1981. Carbonates and relative changes in sea level. Mar. Geol, 44: 181-212.

Kenyon, P.M. and Turcotte, D.L., 1985. Morphology of a delta prograding by bulk sediment transport. Geol. Soc. Am. Bull., 96: 1457-1465.

Lawrence, D.T., Doyle, M. and Aigner, T., 1990. Stratigraphic simulation of sedimentary basins: Concepts and calibration. Am. Assoc. Pet. Geol. Bull., 74: 273-295.

Leopold, L.B. and Bull, W.B., 1979. Base level, aggradation, and grade. Proc. Am. Philos. Soc., 123: 168-202.

Loutit, T.S., Hardenbol, J., Vail, P.R. and Baum, G.R., 1988. Condensed sections: The key to age determinations and correlation of continental margin sequences. In: C.K. Wilgus, B.S. Hastings, C.G.St.C. Kendall, H.W. Posamentier, C.A. 
Ross and J.C. Van Wagoner (Editors), Sea-Level Changes: An Integrated Approach. Soc. Econ. Paleontol. Mineral. Spec. Publ., 42: 183-213.

Mackin, J.H., 1948. Concept of the graded river. Geol. Soc. Am. Bull., 59: 463-512.

Miller, K.G., Wright, J.D. and Fairbanks, R.G., 1990. Unlocking the ice house: Oligocene-Miocene oxygen isotopes, eustasy, and margin erosion. J. Geophys. Res. in prep.

Mitchum, R.M., Jr., 1977. Seismic stratigraphy and global changes of sea level, part 11: Glossary of terms used in seismic stratigraphy. In: C.E. Payton (Editor), Seismic Stratigraphy - Applications to Hydrocarbon Exploration: Am. Assoc. Pet. Geol. Mem., 26: 205-212.

Mitchum, R.M., Jr. and Van Wagoner, J.C., 1991. High frequency sequences and their stacking patterns: Sequencestratigraphic evidence of high-frequency eustatic cycles. In: W. Schlager and K.T. Biddle (Editors), The Record of Sealevel Fluctuation. Sediment. Geol., 70: 131-160.

Mitchum, R.M., Jr., Vail, P.R. and Sangree, J.B., 1977. Seismic stratigraphy and global changes of sea level, part 6: Stratigraphic interpretation of seismic reflection patterns in depositional sequences. In: C.E. Payton (Editor), Seismic Stratigraphy - Applications to Hydrocarbon Exploration: Am. Assoc. Pet. Geol. Mem., 26: 117-133.

Mutti, E., 1985. Turbidite systems and their relations to depositional sequences. In: G.G. Zuffa (Editor), Provenance of Arenites. Reidel, Boston, pp.65-93.

Nummedal, D., 1990. Sequence stratigraphic analysis of upper Turonian and Coniacian strata in the San Juan basin, New Mexico, U.S.A. In: R.N. Ginsburg and B. Beaudoin (Editors), Cretaceous Resources, Events and Rhythms. (NATO ASI Series C, Vol. 304.) Kluwer, Dordrecht, The Netherlands, pp.33-46.

Nummedal, D. and Swift, D.J.P., 1987. Transgressive stratigraphy at sequence-bounding unconformities: Some principles derived from Holocene and Cretaceous examples. In: D. Nummedal, O.H. Pilkey and J.D. Howard (Editors), SeaLevel Fluctuation and Coastal Evolution. Soc. Econ. Paleontol. Mineral. Spec. Publ., 41: 241-260.

Nummedal, D., Wright, R., Swift, D.J.P., Tillman, R.W. and Wolter, N.R., 1989. Depositional systems architecture of shallow marine sequences. In: D. Nummedal and R.R. Remy (Editors), Cretaceous Shelf Sandstones and Shelf Depositional Sequences, Western Interior Basin, Utah, Colorado and New Mexico. 28th Int. Geol. Congr. Field Trip Guideb. T119. Am. Geophys. Union, Washington, D.C., pp.35-80.

Olsen, P.E., 1986. A 40-million-year lake record of early Mesozoic orbital climatic forcing. Science, 234: 842-848.

Penland, S., Boyd, R. and Suter, J.R., 1988. Transgressive depositional system of the Mississippi delta plain: a model for barrier shoreline and shelf sand development. J. Sediment. Petrol., 58: 932-949.

Pitman, W.C., III, 1978. Relationship between eustacy and stratigraphic sequences of passive margins. Geol. Soc. Am. Bull., 89: 1389-1403.

Pitman, W.C., III, 1990. Large rapid sea level changes. Earth Planet. Sci. Lett., in prep.

Pitman, W.C., III and Golovchenko, X., 1983. The effect of sealevel change on the shelf edge and slope of passive margins. In: D.J. Stanley and G.T. Moore (Editors), The
Shelfbreak: Critical Interface on Continental Margins. Soc. Econ. Paleontol. Mineral. Spec. Publ., 33: 41-58.

Playford, P.E., 1980. Devonian "Great Barrier Reef" of Canning basin, Western Australia. Am. Assoc. Pet. Geol. Bull., 64: 814-840.

Playford, P.E., Hurley, N.F., Kerans, C. and Middleton, M.F., 1989. Reefal platform development, Devonian of the Canning basin, Western Australia. In: P.D. Crevello, J.L. Wilson, J.F. Sarg and J.F. Read (Editors), Controls on Carbonate Platform and Basin Development. Soc. Econ. Paleontol. Mineral. Spec. Publ., 44: 187-202.

Posamentier, H.W. and Vail, P.R., 1988. Eustatic controls on clastic deposition II -- Sequence and systems tract models. In: C.K. Wilgus, B.S. Hastings, C.G.St.C. Kendall, H.W. Posamentier, C.A. Ross and J.C. Van Wagoner (Editors), Sea-Level Changes: An Integrated Approach. Soc. Econ. Paleontol. Mineral. Spec. Publ., 42: 125-154.

Posamentier, H.W., Jervey, M.T. and Vail, P.R., 1988. Eustatic controls on clastic deposition I - Conceptual framework. In: C.K. Wilgus, B.S. Hastings, C.G.St.C. Kendall, H.W. Posamentier, C.A. Ross and J.C. Van Wagoner (Editors), Sea-Level Changes: An Integrated Approach. Soc. Econ. Paleontol. Mineral. Spec. Publ., 42: 109-124.

Reynolds, D.J., Steckler, M.S. and Coakley, B.J., 1990. The role of the sediment load in sequence stratigraphy: The influence of flexural isostasy and compaction, J. Geophys. Res., in press.

Ross, W.C., 1990. Modeling base-level dynamics as a control on basin-fill geometries and facies distribution: A conceptual framework. In: T.A. Cross (Editor), Quantitative Dynamic Stratigraphy. Prentice-Hall, Englewood Cliffs, N.J., pp.387-399.

Sarg, J.F., 1988. Carbonate sequence stratigraphy. In: C.K Wilgus, B.S. Hastings, C.G.St.C. Kendall, H.W. Posamentier, C.A. Ross and J.C. Van Wagoner (Editors), Sea-Level Changes: An Integrated Approach. Soc. Econ. Paleontol. Mineral. Spec. Publ., 42: 155-181.

Sarg, J.F., 1989. Middle-late Permian depositional sequences, Permian basin, west Texas and New Mexico. In: A.W. Bally (Editor), Atlas of Seismic Stratigraphy. Am. Assoc. Pet. Geol. Stud. Geol., 27 (3): 140-154.

Schlager, W., 1981. The paradox of drowned reefs and carbonate platforms. Geol. Soc. Am. Bull., 92: 197-211 (part 1).

Schlager, W., 1989. Drowning unconformities on carbonate platforms. In: P.D. Crevello, J.L. Wilson, J.F. Sarg and J.F. Read (Editors), Controls on Carbonate Platform and Basin Development. Soc. Econ. Paleontol. Mineral. Spec. Publ., 44: $15-25$.

Schlager, W. and Camber, O,, 1986. Submarine slope angles, drowning unconformities, and self-erosion of limestone escarpments. Geology, 14: 762-765.

Schlee, J.S. (Editor), 1984. Interregional Unconformities and Hydrocarbon Accumulation. Am. Assoc. Pet. Geol. Mem., 36: $184 \mathrm{pp}$.

Sloss, L.L., 1963. Sequences in the cratonic interior of North America. Geol. Soc. Am. Bull., 74: 93-113.

Sloss, L.L., 1988. Forty years of sequence stratigraphy. Geol. Soc. Am. Bull., 100: 1661-1665.

Snow, R.S. and Slingerland, R.L., 1987. Mathematical modeling of graded river profiles. J. Geol., 95: 15-33. 
Steckler, M.S. and Watts, A.B., 1978. Subsidence of the Atlantic-type continental margin off New York. Earth Planet. Sci. Lett., 41: 1-13.

Steckler, M.S. and Watts, A.B., 1982. Subsidence history and tectonic evolution of Atlantic-type continental margins. In: R.A. Scrutton (Editor), Dynamics of Passive Margins. Am. Geophys. Union Geodyn. Ser., 6: 184-196.

Swain, F.M., 1949. Onlap, offlap, overstep, and overlap. Am. Assoc. Pet. Geol. Bull., 33: 634-636.

Swift, D.J.P., 1968. Coastal erosion and transgressive stratigraphy. J. Geol., 76: 444-456.

Swift, D.J.P. and Thorne, J.A., 1990. Sedimentation on continental shelves. Part I: A general model for shelf sedimentation. In: D.J.P. Swift, G.F. Oertel and R.W. Tillman (Editors), Shelf Sands and Sandstone Bodies: Geometry, Facies and Distribution. Int. Assoc. Sedimentol. Spec. Publ., in press.

Swift, D.J.P., Hudelson, P.M., Brenner, R.L. and Thompson, P., 1987. Shelf construction in a foreland basin: storm beds, shelf sandbodies, and shelf-slope depositional sequences in the Upper Cretaceous Mesaverde Group, Book Cliffs, Utah. Sedimentology, 34: 423-457.

Thorne, J.A. and Swift, D.J.P., 1990. Sedimentation on continental shelves. Part II: Application of the regime concept. In: D.J.P. Swift, G.F. Oertel and R.W. Tillman (Editors), Shelf Sands and Sandstone Bodies: Geometry, Facies and Distribution. Int. Assoc. Sedimentol. Spec. Publ., in press.

Thorne, J. and Watts, A.B., 1984. Seismic reflectors and unconformities at passive continental margins. Nature, 311 : 365-368.

Vail, P.R., 1987. Seismic stratigraphy interpretation using sequence stratigraphy. Part I: Seismic stratigraphy interpretation procedure. In: A.W. Bally (Editor), Atlas of Seismic Stratigraphy. Am. Assoc. Pet. Geol. Stud. Geol., 27 (1): $1-10$.

Vail, P.R., Mitchum, R.M., Jr., Todd, R.G., Widmier, J.M., Thompson, S., III, Sangree, J.B., Bubb, J.N. and Hatlelid, W.G., 1977. Seismic stratigraphy and global changes of sea level. In: C.E. Payton (Editor), Seismic Stratigraphy Applications to Hydrocarbon Exploration: Am. Assoc. Pet. Geol. Mem., 26: 49-212.

Vail, P.R., Hardenbol, J. and Todd, R.G., 1984. Jurassic unconformities, chronostratigraphy, and sea-level changes from seismic stratigraphy and biostratigraphy. In: J.S. Schlee (Editor), Interregional Unconformities and Hydrocarbon Accumulation. Am. Assoc. Pet. Geol. Mem., 36: $129-144$.

Van Hinte, J.E., 1978. Geohistory analysis - application of micropaleontology in exploration geology. Am. Assoc. Pet. Geol. Bull., 62: 201-222.

Van Wagoner, J.C., Mitchum, R.M., Jr., Posamentier, H.W. and Vail, P.R., 1987. Seismic stratigraphy interpretation using sequence stratigraphy. Part II: Key definitions of sequence stratigraphy. In: A.W. Bally (Editor), Atlas of Seismic Stratigraphy. Am. Assoc. Pet. Geol. Stud. Geol., 27 (1): 11-14.

Van Wagoner, J.C., Posamentier, H.W., Mitchum, R.M., Jr., Vail, P.R., Sarg, J.F., Loutit, T.S. and Hardenbol, J., 1988. An overview of the fundamentals of sequence stratigraphy and key definitions. In: C.K. Wilgus, B.S. Hastings, C.G.St.C. Kendall, H.W. Posamentier, C.A. Ross and J.C. Van Wagoner (Editors), Sea-Level Changes: An Integrated Approach. Soc. Econ. Paleontol. Mineral. Spec. Publ., 42: 39-45.

Van Wagoner, J.C., Mitchum, R.M., Campion, K.M. and Rahmanian, V.D., 1990. Siliciclastic Sequence Stratigraphy in Well Logs, Cores, and Outcrops: Concepts for HighResolution Correlation of Time and Facies. Am. Assoc. Pet. Geol. Methods Explor. Ser., 7: 55 pp.

Watkins, J.S. and Mountain, G.S. (Convenors), 1990. Role of ODP drilling in the investigation of global changes in sea level. Rep. JOI/USSAC Workshop.

Watts, A.B. and Thorne, J., 1984. Tectonics, global changes in sea level and their relationship to stratigraphical sequences at the U.S. Atlantic continental margin. Mar. Pet. Geol., 1: 319-339

Weimer, R.J., 1990. Sequence stratigraphy and paleotectonics, Denver basin area of Lower Cretaceous foreland basin, U.S.A. In: R.N. Ginsburg and B. Beaudoin (Editors), Cretaceous Resources, Events and Rhythms. (NATO ASI Series C, Vol. 304.) Kluwer, Dordrecht, The Netherlands, pp.23-32.

Wheeler, H.E., 1958. Time-stratigraphy. Am. Assoc. Pet. Geol. Bull., 42: 1047-1063.

Wheeler, H.E., 1964. Base level, lithosphere surface, and timestratigraphy. Geol. Soc. Am. Bull., 75: 599-610. 